\title{
Model Pelatihan Bisnis Online pada Masyarakat Desa sebagai Bentuk Kolaborasi Perguruan Tinggi dan Pesantren
}

\author{
Solihin Solihin \\ (UIN Sunan Sunan Gunung Djati, Bandung; choinsolihin65@,uinsgd.acid) \\ Adnan Adnan \\ (UIN Sunan Sunan Gunung Djati, Bandung; adnanbz99@gmail.com)
}

\begin{abstract}
Community service activities show that universities as part of the community can remain closely connected with the community that gave birth to it. For example, the problem of poverty that continues to haunt social life must continue to be eradicated. That can be alleviated for example by entrepreneurship or business development. Meanwhile, business development continues to grow from time to time so that the online business is rife. With this dedication we can see that people must share knowledge and experience so that they can develop together. Therefore, answers from academics to the problem and society can be displayed here. With the participatory action research method, it was found that the way to increase the understanding and knowledge of religious teachers and students of pesantren towards online business is to begin with interaction. Interactions arising from online business training can be seen the difference through the accuracy of the delivery of information through the appropriate target audience, equipment and communication facilities between creative actors, and budget conditions in meeting the training needs and creativity of students / communities.
\end{abstract}

Keywords: e-commerce, entrepreneurship, rural communities, business training

\begin{abstract}
Abstrak
Kegiatan pengabdian kepada masyarakat ini menampilkan bahwa perguruan tinggi sebagai bagian dari masyarakat dapat tetap berhubungan erat dengan masyarakat yang melahirkannya. Misalnya, masalah kemiskinan yang terus menghantui kehidupan sosial harus terus diberantas. Hal itu dapat dientaskan misalnya dengan wirausaha atau pengembangan bisnis. Sementara itu, pengembangan bisnis terus berkembang dari waktu ke waktu sehingga sampailah pada maraknya bisnis online. Dengan pengabdian ini kami dapat melihat bahwa masyarakat harus saling berbagi ilmu dan pengalaman agar sama-sama dapat berkembang. Oleh karena itu, jawaban-jawaban dari para akademisi atas permasalahan dan masyarakat dapat ditampilkan di sini. Dengan metode participatory action research, ditemukan bahwa cara meningkatkan pemahaman dan pengetahuan ustadz/ah dan santri pesantren terhadap bisnis online adalah dimulai dengan interaksi. Interaksi yang timbul dengan adanya pelatihan bisnis online dapat diketahui perbedaannya lewat ketepatan penyampaian informasi melalu target audience yang sesuai, perlengkapan sarana dan fasilitas
\end{abstract}


komunikasi antar para pelaku kreatif, dan kondisi budget dalam memenuhi kebutuhan pelatihan maupun kreativitas santri/masyarakat.

Kata Kunci: e-commerce, kewirausahaan, masyarakat pedesaan, pelatihan bisnis

\section{A. PENDAHULUAN}

Secara nasional, Indonesia masih mempunyai banyak kemajuan. Yaitu dengan adanya pertumbuhan ekonomi yang menanjak. Dari segi pertumbuhan ekonomi, persentase pun sudah menaik, yaitu sampai angka 6,4\% pada tahun 2011. Hal ini dapat menjadi kabar yang cukup menggembirakan. Kondisi kemiskinan pula sudah mulai menurun angkanya. Walaupun begitu, pada tahun 2010, kondisi kemiskinan masih ada di angka 31 juta penduduk (13.5\% dari keseluruhan jumlah penduduk). Kabar buruknya adalah bahwa 60\% kemiskinan itu ada di daerah pedesaan (Prihartono, 2012).

Dari segi pembangunan daerah, Jawa Barat memiliki potensi pembangunan yang dapat dikembangkan menjadi potensi yang dapat memberikan kesejahteraan bagi masyarakat. Potensi Jawa Barat yang demikian kaya dengan sumber daya alam dan manusia menjadi menarik karena potensi-potensi tersebut masih perlu digali dan dikembangkan secara optimal sehingga mampu memberikan manfaat yang maksimal untuk kesejahteraan.

Pengembangan masyarakat sudah sewajarnya memiliki orientasi kebermanfaatan untuk kesejahteraan. Isu globalisasi dalam berbagai aspek, masalah kemiskinan dan pengangguran, masalah kerusakan alam, dan lain-lain merupakan satu kesatuan yang tidak dapat dipisahkan, manakala berbagai cara mencari solusi dilakukan, termasuk penggunaan teknologi mutakhir. Demikian karena menurut Manning (1994), 
perbedaaan upah dan praktek-praktek di pasar tenaga kerja lebih diakibatkan karena diterapkannya teknologi baru.

Eksistensi demam digital memang sedang naik daun di Indonesia, nyaris tidak ada aspek kehidupan manusia yang lepas dari kehadiran teknologi informasi, kehadiran televisi, handphone, komputer, dan internet merupakan berbagai perangkat teknologi informasi yang dengan cepat mengubah pola kehidupan dan gaya hidup masyarakat. Dari situlah muncul berbagai pengembangan dibidang industri kreatif. Seperti yang diketahui bahwa cangkupan industri kreatif sangatlah banyak mulai dari seni, musik, perfilman, periklanan dan lain sebagainya. Ditambah dengan memasuki era industri 4.0 transformasi mulai dirasakan secara praktis dan kompleks dalam berbagai sektor. Seperti halnya dari pola interaksi / berkomunikasi yang terjadi tidak hanya antar manusia, manusia antar mesin, dan mesin antar mesin itu sendiri sehingga interaksi ini berdampak pada terciptanya manajemen pengetahuan. Revolusi ini juga membawa dampak pada aktivitas interaksi manusia pada ruang tertentu, seperti halnya media sosial yang juga sering dimanfaatkan untuk memperluas target pencapaian sebuah aktivitas komunikasi karena adanya fasilitas yang mewadahi multi interaksi. Maka dengan adanya "Internet of things" para pelaku di industri kreatif pun semakin marak dan berkembang hal ini dapat dibuktikan dengan banyaknya anak muda yang ingin menjadi konten kreator dengan bantuan media sosial, sekedar untuk eksistensi dan meraup penghasilan.

Proses interaksi simbolik melalui sosialisasi adalah proses yang lebih dinamis yang memungkinkan manusia mengembangkan kemampuan untuk berpikir, untuk mengembangkan cara hidup manusia tersendiri. Sosialisasi bukanlah semata-mata 
proses satu arah di mana aktor menerima informasi, tetapi merupakan proses dinamis di mana aktor menyusun dan menyesuaikan informasi tersebut dengan kebutuhan mereka sendiri. Semua jenis interaksi tak hanya interaksi selama sosialisasi, namun juga memperbesar kemampuan kita untuk berpikir lebih dari itu (Ritzer, 2014: 274).

Maka, dapat dilihat proses interaksi simbolik yang terdapat dalam hubungan timbal balik antara kreator dan masyarakat di Pesantren Persis No. 97 Cikajang, Garut. Hubungan antara keduanya timbul sebagai hubungan asosiatif yaitu kerja sama (Co-operation), kerja sama dapat terjadi karena didorong oleh kesamaan tujuan atau manfaat yang akan diperoleh dalam kelompok tersebut. Kerja sama menurut Charles H. Cooley (Soekanto, 1986: 62) yaitu timbul jika orang menyadari bahwa mereka mempunyai cukup pengetahuan dan pengendalian terhadap diri sendiri untuk memenuhi kepentingan ini melalui kerja sama, kesadaran akan adanya kepentingan yang sama dan adanya organisasi merupakan fakta-fakta yang penting dalam kerja sama yang berguna.

Hal ini terjadi dikarenakan baik kreator maupun peserta memiliki tujuan dan misi yang sama dalam pengembangan passion. Dengan mengadakan event atau pelatihan para kreator berkesempatan membangun relasi yang lebih luas untuk memperkenalkan karya mereka, sedangkan peserta mendapatkan wawasan dan pengalaman tentang bidang yang akan mereka tempuh.

Adapun sasaran yang dituju dalam pengabdian berupa pelatihan ini adalah kelompok masyarakat pembelajar, yaitu ustadz/ah dan santri dari sebuah pesantren di Garut. Pesantren tersebut, yaitu Pesantren Persatuan Islam No. 97 berlokasi di Desa Cikandang, Kecamatan Cikajang, Kabupaten Garut. Kondisi masyarakat yang berada 
di perdesaan membuat pihak pesantren sendiri seringkali kebingungan menghadapi kebanyakan anak didik yang orang tuanya tidak mampu membayar biaya pembelajaran, termasuk sarana dan prasarana pembelajaran (Wawancara dengan PZ, ustadz, 9/9/2019).

Namun demikian, ada potensi-potensi yang dapat membuat para guru dan murid di desa ini maju, yaitu potensi "angkatan kerja" atau para santri itu sendiri yang masih banyak tenaga dan pikiran untuk melakukan langkah-langkah positif untuk bekal mereka nanti. Yang kedua adalah kondisi pertanian dan alamiah desa di sekeliling yang berpotensi untuk dikembangkan menjadi bahan-bahan untuk dibuat dalam bisnis online.

Dari analisis situasi tersebut di atas, dapat dirumuskan beberapa masalah sebagai berikut: "Bagaimana cara meningkatkan pemahaman dan pengetahuan ustadz/ah dan santri pesantren terhadap bisnis online?" dan "Bagaimana transmisi pengetahuan pihak pesantren kepada masyarakat?"

\section{B. TINJAUAN PUSTAKA}

\section{Pemberdayaan Oleh Lembaga Pendidikan}

Perguruan Tinggi merupakan kelanjutan pendidikan menengah yang diselenggarakan untuk mempersiapkan peserta didik agar menjadi anggota masyarakat yang memiliki kemampuan akademis dan professional yang dapat menerapkan, mengembangkan dan menciptakan ilmu pengetahuan, teknologi dan kesenian (UU Nomor 2 Tahun 1989, Pasal 16, ayat 1). 
Perguruan Tinggi merupakan wadah bagi masyarakat kampus. Sebagai suatu organisasi, maka Perguruan Tinggi mempunyai (1) struktur, (2) aturan penyelesaian tugas, yang mencakup pembagian tugas antar kelompok fungsional dan antar warga dalam kelompok yang sama, (3) rencana kegiatan, dan (4) tujuan. Tujuan dibimbing oleh asas dan membimbing rencana kegiatan. Struktur dan aturan penyelesaian tugas menjadi prasarana pencapaian tujuan dan sekaligus mencerminkan asas. Peranan Perguruan Tinggi harus dapat menciptakan sumber daya manusia yang berkualitas serta memiliki potensi untuk menentukan masa depan yang lebih baik (Fadjar, 2005: 258).

Pasal 34 ayat 2 Peraturan Pemerintah No 2 Tahun 1990, menjelaskan bahwa tujuan Perguruan Tinggi adalah sebagai berikut: “(1) Menyiapkan peserta didik menjadi anggota masyarakat yang memiliki kemampuan akademik dan atau profesional yang dapat menerapkan, mengembangkan atau menciptakan ilmu pengetahuan, teknologi dan atau kesenian. (2) Mengembangkan dan menyebarluaskan ilmu pengetahuan, teknologi dan atau kesenian serta mengupayakan penggunaannya untuk meningkatkan taraf kehidupan masyarakat dan memperkaya kebudayaan nasional" (Sudiyono, 2004: 2).

Intinya, Perguruan Tinggi memiliki tujuan yang luas bagi peserta didik dalam pengembangan ilmu pengetahuan, teknologi dan kesenian. Sehingga peserta didik dapat mengaplikasikannya ketika berada di lingkungan masyarakat dengan mudah.

Sementara itu, pesantren menurut pengertian pada dasarnya adalah tempat belajar para santri, sedangkan pondok berarti rumah atau tempat tinggal sederhana terbuat dari bambu. Menurut Dhofier (1984: 18), „di Jawa termasuk Sunda dan 
Madura umumnya digunakan istilah Pondok Pesantren, sedangkan di Aceh dikenal dengan istilah dayah atau rangkang. Dan di Minangkabau disebut Surau.“

Menurut pendapat Nurcholis (Nata, 2001: 91), kata “santri” berasal dari kata sastri (Sansekerta) yang berarti “melek huruf", senada dengan itu perkataan santri juga berasal dari bahasa Jawa (catrik) yang berarti orang yang selalu mengikuti seorang guru kemana guru pergi menetap, tentu dengan tujuan agar dapat belajar dari guru mengenai suatu keahlian.

Istilah "pondok" diambil dari khazanah bahasa Arab "funduq" yang berarti ruang tidur, wisma atau hotel sederhana. Dalam dunia pesantren, pondok merupakan unsur penting karena fungsinya sebagai tempat tinggal atau asrama santri, sekaligus untuk membedakan apakah lembaga tersebut layak dinamakan pesantren atau tidak. Mengingat terkadang sebuah masjid atau bahkan musholla setiap saat ramai dikunjungi oleh kalangan mereka yang bersungguhsungguh dalam menuntut ilmu agama, akan tetapi tidak dikenal sebagai pesantren lantaran tidak memiliki bangunan pondok atau asrama santri (Ziemek, 1986: 98).

Pengertian pesantren diturunkan dari bahasa India sastri yang berarti ilmuwan Hindu yang pandai menulis, maksudnya pesantren adalah tempat bagi orang-orang yang pandai membaca dan menulis. Geertz menganggap bahwa pesantren dimodifikasi dari pura Hindu (Wahjoetomo, 1997: 70).

Pondok pesantren adalah suatu lembaga pendidikan agama Islam yang tumbuh serta diakui oleh masyarakat sekitar, dengan sistem asrama (kampus) yang santrisantrinya menerima pendidikan agama melalui sistem pengajian atau madrasah yang sepenuhnya berada di bawah kedaulatan dan kepemimpinan seorang atau 
beberapa orang kyai dengan ciri-ciri khas yang bersifat kharismatis serta independen dalam segala hal (Djamaluddin, \& Abdullah Aly, 1998: 99).

Dikatakan pula bahwa „pondok pesantren adalah suatu bentuk lingkungan ,masyarakat ${ }^{6}$ yang unik dan memiliki tata nilai kehidupan yang positif. Pada umumnya, pesantren terpisah dari kehidupan sekitanya. Komplek pondok pesantren minimal terdiri atas rumah kediaman pengasuh disebut juga kyai, masjid atau mushola, dan asrama santri. Tidak ada model atau patokan tertentu dalam pembangunan fisik pesantren, sehingga penambahan bangunan demi bangunan dalam lingkungan pesantren hanya mengambil bentuk improvisasi sekenanya belaka“ (Wahjoetomo, 1997: 65).

Kelahiran pesantren baru, selalu diawali dengan cerita perang nilai antara pesantren yang akan berdiri dengan masyarakat sekitarnya, dan diakhiri dengan kemenangan pihak pesantren. Bahkan dengan kehadiran pesantren dengan jumlah santri yang banyak dan datang dari berbagai masyarakat lain yang jauh, maka terjadilah semacam kontak budaya antara berbagai suku dan masyarakat sekitar. Dari segi kultur para ulama Islam berusaha menghindarkan tradisi serta ajaran agama Islam dari pengaruh kebudayaan Barat. Segala sesuatu yang berbau Barat secara apriori ditolak oleh mereka, termasuk sistem Pendidikan (Arifin, 2003: 229).

Kemudian, secara konseptual pemberdayaan dan pemberkuasaan, berasal dari kata power yang berarti kekuasaan atau keberdayaan. Konsep pemberdayaan berawal dari penguatan modal sosial di masyarakat, apabila kita sudah mempunyai kepercayaan, patuh aturan, dan jaringan. Memiliki modal sosial yang kuat kita akan mudah mengarahkan dan mengatur masyarakat serta mudah mentransfer ilmu kepada 
masyarakat, Konsep ini mengandung arti bahwa konsep pemberdayaan masyarakat adalah transfer kekuasaan melalui penguatan modal sosial ini lah menjadikan kelompok produktif untuk mencapai kesejahteraan sosial.

Pemberdayaan merujuk pada pemberdayaan kemampuan orang, khususunya pada kelompok rentan dan lemah sehingga mereka memiliki kekuatan atau kemampuan dalam:

a. Memenuhi kebutuhan dasarnya sehingga mereka memiliki kebebasan, bukan berarti bebas dalam mengemukakan pendapat melainkan bebas dari kelaparan, bebas dari kebodohan.

b. Menjangkau sumber-sumber produktif yang memungkinkan mereka dapat menigkatkan pendapatannya dan memperoleh barang dan jasa yang mereka perlukan.

c. Berpartisipasi dalam proses pembangunan dan keputusan-keputusan yang mempengaruhi mereka (Suharto, 2005: 86).

Teori Mobilisasi Sumber daya, Gerakan sosial terdiri dari individu - individu dan interaksi di antara anggota masyarkat. Pada konteks pemberdayaan masyarakat maka teori mobilisasi menjadi salah satu dasar yang kuat, karena untuk menjadi seseorang atau kelompok masyarakat yang berdaya atau memiliki power selain uang, knowledge maka people juga mempunyai peranan yang penting. Kumpulan orang akan memberikan kekuatan, kekuatan itu akan menjadi power pada orang atau masyarakat itu.

Beberapa asumsi dari teori mobilisasi sumber daya antara lain: 
1. Organisasi atau lembaga dapat menjadi sarana pengumpulan sumber daya dalam mendukung aktivitas gerakan seperti dana, peralatan, akses media, dll.

2. Proses perubahan dalam suatu masyarakat modern pasti terjadi karena terdapat banyak perbedaan pandangan yang memunculkan ketidakpuasan didalamnya. Hal ini membuat organisasi atau lembaga secara rasional untuk mempertimbangkan segala konsekuensinya dalam satu gerakan (Maarif, 2010: 68).

Di Indonesia, perkembangan ekonomi kreatif didorong dengan diluncurkannya program Indonesia Design Power (IDP) pada 2006. IDP merupakan program untuk meningkatkan daya saing produk-produk Indonesia di pasar domestik maupun ekspor. Selama kurun waktu 10 tahun terakhir, sektor ekonomi kreatif makin berkembang pesat di beberapa kota besar. Melalui inisiatif komunitas anak muda di sejumlah kota, seperti Jakarta, Bandung, dan Yogyakarta industri kreatif telah tumbuh subur dan meningkatkan geliat ekonomi masyarakat. Benih yang memicu pertumbuhan ekonomi kreatif di tingkat lokal telah mampu melahirkan karya film, animasi, fashion, musik, software, game komputer, dan sebagainya. Beberapa di antara pelaku ekonomi kreatif ini malah mendapatkan kesempatan menampilkan karyanya di ajang internasional.

Di Indonesia sendiri saat ini, sedang mengembangkan ekonomi kreatif yang sangat besar sumbangsihnya terhadap kemajuan industri. Hasil dari industry ekonomi kreatif ini seperti seni, musik, fashion, dan periklanan dapat menumbuhkan perekonomi Indonesia. Oleh karena itu, kita perlu mengenali kembali tentang apa yang kita miliki dan menyusun langkah-langkah aksi yang konstruktif (Suryana, 2013). 
Semakin bertumbuhnya kreator muda seperti selebgram, youtuber dan influencer lainnya yang berada dilingkungan industri kreatif. Cukup berperan meningkatkan antusias masyarakat untuk terlibat di dalamnya. Sebut saja tokoh yang sedang hits belakangan ini, yaitu Atta Halilintar, Raditya Dika, Dian Pelangi dan masih banyak lagi para kreator muda sukses menjalani perannya dalam industri kreatif. Dari sanalah muncul keinginan orang-orang awam atau pemula untuk mengikuti jejak mereka, sehingga para pelaku itu pun ingin membantu dalam mendorong generasi muda untuk sukses secara mandiri tanpa bergantung pada pihak lain (Anwar, Lusiana, Rahman, 2019).

Dewasa ini, perekonomian semakin maju dengan kehadiran para perintis baru yang bergerak di bidang teknologi dan kreativitas, menjadi seorang seniman dan konten kreator adalah profesi yang menggiurkan terutama jika bergerak di industri media sosial dan youtube, mulai dari perfilman, fotografi, desainer, animator dan kerajinan. Semua orang bebas menyalurkan idenya, semua orang bebas untuk berkarya dan mengembangkan kreativitasnya melalui pembuatan inovasi sesuai minat dan bakatnya.

Adanya keinginan tersebut, menciptakan hubungan timbal balik antara kreator dengan masyarakat yang menjadi obyek mereka, masyarakat disini menjadi peserta yang mengikuti suatu pelatihan dan pembelajaran langsung dari profesional sehingga mereka mendapatkan keuntungan untuk pengembangan diri. Kelangsungan pembelajaran melalui komunikasi hubungan saling memberikan informasi yang disampaikan masing-masing pihak, melalui kegiatan tersebut seseorang mewujudkan perilaku sebagai reaksi atas maksud yang ingin disampaikan oleh pihak lain. 


\section{Diagnostik Masyarakat Desa}

Tentang masyarakat desa, dapat dikatakan bahwa itu merupakan suatu masyarakat yang mempunyai hubungan erat atas dasar sistem kekeluargaan dan juga masih mempertahankan tradisinya (Soekanto, 2013: 136). Karakteristik masyarakat desa selalu dikontraskan dengan masyarakat yang masih bersahaja, sederhana, dan apa adanya (alami dan damai). Mata pencaharian masyarakatnya lebih dominan pada sektor pertanian, perkebunan, peternakan, dan sejenisnya (Jamaludin, 2015: 18).

Kehidupan masyarakat pedesaan "berbeda dengan masyarakat perkotaan, dalam memahami masyarakat pedesaan dan masyarakat perkotaan tentu tidak akan mendefinisikannya secara universal dan obyektif tetapi berpatokan pada ciri-ciri masyarakat" (Rahman, 2011: 18). Adapun ciri-ciri kehidupan masyarakat desa antara lain: giat bekerja, tolong-menolong, gotong royong, dan bermusyawarah.

Musyawarah adalah satu gejala sosial yang ada dalam banyak masyarakat pedesaan pada umumnya dan kuhusunya masyarakat Indonesia. Artinya ialah, bahwa "keputusan yang diambil dalam rapat tidak berdasarkan suatu mayoritas, yang menganut suatu pendirian tertentu, melainkan seluruh rapat seolah-olah sebagai suatu badan” (Rahman, 2011: 19). Perlu kita ketahui bahwa "musyawarah tidak hanya bisa diartikan sebagai suatu cara berapat atau memecahkan suatu permasalahan namun juga sebagai suatu semangat untuk menjiwai seluruh kebudayaan dan masyarakat" (Rahman, 2018: 22). Jiwa musyawarah itu menurut hemat kami merupakan suatu eksistensi dari jiwa gotong royong. "Tidak hanya dalam rapat-rapat saja tetapi juga dalam kehidupan sosial, warga dari suatu masyarakat yang berjiwa gotong royong 
yaitu diharapkan mampu bertukar pikiran atau mendapat supaya tidak merasa pendapatnya yang paling benar" (Sajogyo, 2011: 24-32).

Masyarakat pedesaan kebanyakan mata pencahariannya adalah petani, masyarakat pedesaan yang berpenghasilan dari pertanian oleh Jhon Mellor dinyatakan sebagai masyarakat yang berpenghasilan rendah. Masyarakat pedesaan pada umumnya dalam upaya untuk memenuhi kebutuhan ekonomi rumah tangga memiliki mata pencaharian di bidang usaha pertanian baik sebagai petani pemilik, petani penggarap maupun sebagai buruh tani dengan usaha sampingan. Namun demikian sangat jarang petani yang memiliki lahan sendiri, kebanyakan mereka pengelola lahan dengan hanya memilki lahan yang sangat sempit.

Jika diikutip pendapat di antara para ahli, bahwa presentase kemiskinan terburuk terdapat di antara kaum tani, yang berarti bahwa daerah pedesaan adalah paling menderita oleh "wabah" kemiskinan. Hal ini disebabkan oleh "mentalitas si miskin itu sendiri, minimnya keterampilan yang dimilkinya, ketidak mampuannya untuk memanfaatkan kesempatan-kesempatan yang disediakan dan peningkatan jumlah penduduk yang relatif berlebihan” (Asy'ari, 1993: 93-4).

Masalah putus sekolah atau drop out merupakan predikat yang diberikan kepada mantan peserta didik yang tidak mampu menyelesaikan suatu jenjang pendidikan, sehingga tidak dapat melanjutkan studinya ke jenjang pendidikan berikutnya. Masalah ini khususnya pada jenjang pendidikan rendah, kemudian tidak bekerja atau pengangguran dapat memeberikan beban bagi masyarakat bahkan sering menjadi pengganggu ketentraman masyarakat. Hal ini diakibatkan kurangnya pendidikan atau pengalaman intelektual, serta "tidak memiliki keterampilan yang dapat menopang 
kehidupannya sehari-hari, lebih-lebih bila mengalami frustasi dan merasa rendah diri tetapi bersifat overkompensasi, bisa menimbulkan gangguan-gangguan dalam masyarakat berupa perbuatan kenakalan yang bertentangan dengan norma-norma sosial yang positif' (Gunawan, 2000: 72).

Pada dasarnya pendidikan merupakan tanggung jawab keluarga, yang mana masyarakat pedesaan juga membutuhkan ilmu agama, ilmu pengetahuan, keterampilan dengan tujuan supaya dirinya nanti mampu menjadi bangsa yang berkepribadian keimanan dan berpengetahuan luas. Dalam rangka mendidik anak tidak semua orang tua mempunyai ilmu yang cukup luas untuk ditransformasikan kepada anak-anaknya, padahal orang tua merupakan faktor yang sangat besar pengaruhnya terhadap kemajuan maupun kemunduran anak dalam belajar. Oleh karena itu orang tua membutuhkan kerja sama dari dulu untuk memaksimalkan proses belajar putra-putrinya. Disinilah “fungsi lembaga pendidikan formal untuk memberikan pendidikan dan pengajaran kepada anak-anak mengenai apa yang dapat atau tidak ada kesempatan orang tua memberikan pendidikan dan pengajaran dalam keluarga" (Zuhairini, 1992: 179).

Ciri-ciri pedesaan yang dibawa oleh masyarakat urban di kota menujukkan pola yang berbeda didasarkan pada ciri-ciri desa asal yang dibawa oleh migrant. Laporan penelitian UNESCO (1959) tentang "desa-kota di Asia yang mengalami proses industrialisasi dan urbanisasi menggambarkan beberapa kota di Asia dan Timur jauh bertentangan dengan kota-kota yang ada di Barat." "Kota-kota itu masih memiliki ciri-ciri pedesaan yang kental atau kebiasaan pengelompokan desa-desa" (Zuhairini, 1992: 179). 
Menurut Moore (1965: 201), "munculnya industrialisasi tidak hanya unsur pokok bagi pertumbuhan ekonomi secara mendasar, tetapi juga mengarah pada penciptaan suatu budaya umum. Proses ini berlangsung secara kontinu yang selalu melibatkan faktor ekonomi, urbanisasi, tranformasi sosial budaya menuju keseimbangan struktur sosial yang baru."

Perubahan masyarakat tradisional (agraris) ke masyarakat industri (modern) akibat "derasnya proses modernisasi dengan berbagai nilai dan teknologi yang ditawarkan” (Soelaiman, 1998: 93). Hal ini karena modernisasi melibatkan perubahan pada hampir segala aspek tingkah laku sosial termasuk didalamnya industrialisasi, urbanisasi, diferensiasi, sekulerisasi, sentralisasi, dan sebagainya. Bahkan modernisasi dianggap sebagai "proses transformasi nilai, yaitu untuk mencapai status modern, struktur dan nilai-nilai tradisional secara total harus diganti dengan seperangkat struktur dan nilai-nilai modern" (Suwarsono, 2006: 23).

Akhirnya, struktur masyarakat agraris yang memiliki nilai-nilai sosial seperti gotong royong yang sangat kuat telah berubah. Pada masyarakat industri terjadi pembagian kerja. Karena kebutuhan masyarakat industri sangat kompleks dan hanya dapat diselesaikan dengan pembagian tugas. Dampak perubahan dari daerah agraris menjadi industri yang signifikan meliputi perubahan mata pencaharian, yaitu terjadi pergeseran orientasi dari sektor pertanian menjadi sektor industri, jasa dan perdagangan. Kenyataan tersebut tidak dapat dielakkan, bahwa "industrialisasi pada masyarakat pertanian (agraris) yang ada di wilayah pedesaan merupakan salah satu penyebab perubahan sosial yang mempengaruhi sistem dan struktur sosial masyarakatnya. Proses industrialisasi diyakini mampu mengubah pola hubungan kerja 
tradisional (buruh tani atau petani) menjadi modern rasional (buruh pabrik atau karyawan)" (Suwarsono, 2006: 24).

Sebagai sesuatu yang baru, industri memunculkan dampak yang sangat beragam bagi kehidupan manusia, baik dampak sosial maupun dampak non sosial seperti pada perubahan fisik kota, pencemaran lingkungan, dan sebagainya. Secara sosial "industrialisasi telah mendorong berbagai perubahan sosial kemasyarakatan" (Basundoro, 2001: 133).

Nilai gemeinschaft antar tenaga kerja dalam kehidupan pertanian tradisional berubah menjadi gesselchaft.Hubungan antara pemilik dan pekerja (atasan dan bawahan) yang semula bersifat kekeluargaan (ataupun patron-clien) berubah menjadi ultilitarian komersial (nilai kebermanfaatan atau kegunaan). Dengan demikian, perubahan sosial yang terjadi di masyarakat pasca-industrialisasi merupakan sebuah keniscayaan, akan tetapi, tidak semua dampak perubahan sosial itu bernada negatif. Ada pula dampak positifnya, yaitu "pada perkembangan tingkat pertumbuhan pendapatan masyarakat pedesaan yang terkait dengan perubahan pola mata pencaharian (kesempatan kerja dan kesempatan berusaha)" (Jamaludin, 2015: 228).

Dampak negatifnya adalah "adanya pencemaran lingkungan (terutama air limbah yang mengaliri lahan pertanian sehingga hasil pertanian menjadi kurang baik), meningkatnya kecemburuan sosial (masyarakat desa yang semula hidup apa adanya, kemudian berubah memiliki penghasilan yang akhirnya menimbulkan persaingan), munculnya kesenjangan masyarakat desa-kota (khususnya persaingan meraih kesempatan kerja dan pendapatan karena perbedaan produktivitas pertanian dan non 
pertanian akibat makin terbatasnya lahan usaha tani, tingkat pendidikan, dan keterampilan)" (Jamaludin, 2015: 229).

Pengaruh masuknya industri ke kawasan agraris (desa) telah menjadikan masyarakat tradisional, desa, dan agraris secara alami ikut berubah menjadi masyarakat modern, kota, kelurahan, dan industri. Salah satunya adalah "perubahan status desa menjadi kelurahan. Bahkan salah satu syarat dari perubahan status desa menjadi kelurahan adalah adanya kondisi sosial budaya masyarakat berupa keanekaragaman status penduduk dan perubahan nilai agraris ke jasa industri”" (Rahman, 2011: 76).

Di samping perubahan seperti halnya di atas, perubahan juga terjadi pada pola perilaku ekonomi, pola pikir serta gaya hidup masyarakat. Hal ini menggambarkan karakteristik dari masyarakat modern atau masyarakat kota. Misalnya, perubahan dari perilaku ekonomi masyarakat, salah satunya adalah pola hidup kesehariannya lebih konsumtif. Hal ini diakibatkan dari "pekerjaan yang menghasilkan gaji tetap dan cukup dibandingkan sebelumnya saat pekerjaananya sebagai petani” (Jamaludin, 2015: 220).

Bahkan, berubahnya tingkat pendapatan juga berpengaruh pada pandangan masyarakat tentang menginventasikan pendapatan yang diperolehnya. Maka, "jika dahulu masyarakat lebih senang menginventasikan pendapatannya untuk membeli sebidang tanah atau binatang ternak (sapi, kerbau, kambing, ayam, atau itik) sebagai tabungan masa depannya, sekarang mereka lebih senang mengiventasikan pendapatannya dalam tabungan dan bentuk kendaraan (seperti sepeda motor, mobil atau lainnya) karena sepeda motor dianggap lebih dapat meningkatkan prestise 
seseorang dalam masyarakat dibandingkat dengan kepemilikan hewan ternak atau menabung” (Rahman, 2011: 76).

Semakin majunya tingkat pendidikan, semakin terspesialisasinya bidang pekerjaan dan karier, artinya ada kebutuhan untuk keahlian khusus membuat masyarakat mengikuti kursus ataupun pelatihan. Hal ini pula yang memicu kebutuhan akan pendidikan dan sekolah bagi masyarakat. Hingga masyarakat yang tadinya cukup berpendidikan SD, lambat laun meningkat menjadi SMA dan perguruan tinggi.Pihak pabrik pun tidak menerima para pekerja yang berpendidikan SD. Dengan demikian, "antara pihak pabrik dan masyarakat berkolerasi dalam memajukan pendidikan masyarakat secara tidak langsung” (Jamaludin, 2015: 230).

Begitupun dalam hal pakaian yang digunakannya. Pakaian bermerek, terkenal, gaya dan modis, sudah menjadi bagian gaya hidup mereka. Dengan demikian "penggunaan alat teknologi yang maju menunjukkan masyarakat semakin hedonisme dalam hidupnya" (Jamaludin, 2015: 230).

Pertemanan (persahabatan), pergaulan serta komunikasi sudah banyak yang berubah. Gaya hidup masyarakat hanya berteman dengan orang-orang pabrik dan sesama pekerja atau setingkat. Pergaulan mereka tidak dibatasi waktu dan tempat. Komunikasi yang dilakukannya tidak lagi menggunakan bahasa daerah, "tetapi memakai bahasa atau istilah kota juga bahasa yang sedang tren saat ini” (Rahman, 2011: 75).

\section{Kerangka Pemecahan Masalah}

Program pelatihan bisnis online dapat mengacu kepada "komunikasi instruksional yang didasari oleh teori S-O-R atau S-O-R Theory yang merupakan 
singkatan dari Stimulus - Organism - Response" (Effendy, 2000: 254). Adapun respon yang diharapkan dalam komunikasi instruksional ini sesuai dengan taksonomi dari Bloom, bertumpu pada tiga domain yaitu "menambah pengetahuan, membentuk sikap dan memberikan keterampilan (kognitif, afektif dan psikomotorik)" (Yusup, 1990: 22), sehingga manifestasinya dapat berupa: "Kognitif, yaitu penambahan materi pengetahuan berupa fakta, informasi, prinsip, prosedur, penguasaan pola-pola berfikir, mengingat atau mengenali kembali; Afektif, yaitu sikap-sikap apresiasi; dan Psikomotorik, yaitu keterampilan-keterampilan yang bersifat ekspresif' (Makmun, 2002: 160-161).

Dengan demikian, pelatihan ini diharapkan para peserta pelatihan dapat menambah wawasan, memiliki sikap dan keterampilan yang berkaitan dengan caracara melakukan bisnis online.

Komunikasi instruksional ini tidak akan mendapatkan respon yang sesuai harapan jika tidak mengandung unsur dialogis dan kesamaan di antara komunikator dan komunikan, karena proses pembelajaran tidak terjadi satu arah melainkan timbal balik (interactive, two way traffic system) sehingga kedua pihak berperan dan berbuat secara aktif di dalam suatu kerangka kerja (frame work) dengan menggunakan kerangka berfikir (frame of reference) yang dipahami bersama. Komunikasi instruksional dalam bentuk pembelajaran dan pelatihan ini menekankan pada makna belajar (learning). Menurut Crow \& Crow (Makmun, 2002: 157), "belajar adalah proses perubahan perilaku atau pribadi seseorang berdasarkan praktek atau pengalaman tertentu." Di Vesta \& Thompson (Makmun, 2002: 157) menggambarkan proses perubahannya sebagai berikut: 


\section{Gambar 1. Proses Pembelajaran}

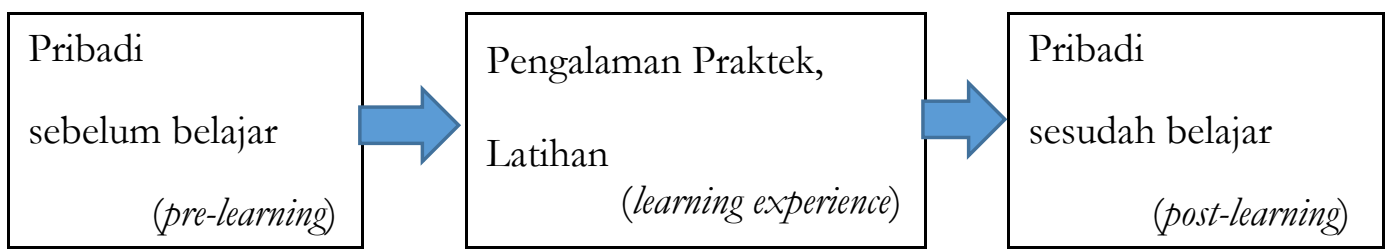

Sumber: (Makmun, 2002: 157)

Di dalam proses pembelajaran seperti yang terjadi di dalam pelatihan bisnis online ini, melibatkan unsur sumber dan penerimaan sebagai satu kesatuan yang tak terpisahkan. Sumber adalah seorang pembicara atau instruktur yang memberikan pengetahuan dan mentransfer keahlian kepada pihak yang diajarinya. Kualitas seorang pembicara atau instruktur, oleh McCroskey dinyatakan sebagai kredibilitas pembicara (DeVito, 1997: 459). Komunikan tidak akan mempercayai isi pesan yang disampaikan oleh komunikator yang dianggap tidak memiliki kredibilitas maka di dalam setiap proses komunikasi kredibilitas komunikator akan mempengaruhi efektivitas penyampaian pesan kepada komunikan.

Tiga aspek kualitas utama dari kredibilitas adalah kompetensi, karakter dan karisma yang dapat diuraikan sebagai berikut: "Kompetensi, mengacu kepada pengetahuan dan kepakaran yang menurut khalayak dimiliki oleh pembicara; Karakter, mengacu pada itikad dan perhatian pembicara kepada khalayak; Kharisma, mengacu pada kepribadian dan kedinamisan pembicara” (DeVito, 1997 : 459).

Dengan demikian melalui pelatihan ini diharapkan para peserta pelatihan dapat menambah wawasan, memiliki sikap dan keterampilan yang berkaitan dengan caracara melakukan bisnis online. Disinilah maka, kompetensi pembicara harus 
mencakup sifat "knowledgeable, experienced, confident dan informed, sedangkan yang termasuk ke dalam aspek karakter adalah fair, concerned, consistent dan similar, aspek terakhir yang menjadi unsur karisma antara lain positive, assertive, enthusiastis dan active" (DeVito, 1997: 460-461). Dengan demikian unsur pengetahuan, pengalaman, kepercayaan diri, informatif, adil, kepedulian, konsistensi, kesamaan, sikap positif, ketegasan, semangat dan keaktifan menjadi unsur yang dilihat oleh komunikan pada diri seorang instruktur.

Mengacu pada latar belakang dan perbincangan teoretis di atas, maka untuk pelatihan bisnis online ini seyogyanya dipilih pembicara atau instruktur yang memiliki pengetahuan, pengalaman dan keterampilan dalam menjalin hubungan baik dengan masyarakat, sekaligus mengalami atau minimal mengetahui tentang seluk-beluk bisnis online. Demikian sehingga masyarakat dapat mengambil manfaat secara lebih berbuah lagi, bahkan dapat langsung dipraktekkan pengetahuannya tersebut dalam kehidupan sehari-hari mereka.

\section{METODE}

Pengabdian ini membutuhkan dukungan dari aktor pembangunan yang dilakukan di perdesaan. Selain itu, juga dilibatkan banyak pihak yang berkaitan erat dengan program pengabdian di tempat tersebut yaitu tokoh masyarakat di kawasan tersebut, warga sekitar yang secara langsung menyukseskan kegiatan, aparat desa, hingga Dinas Kebudayaan dan Pariwisata atau pihak pemerintahan atau swasta terkait lainnya yang mendukung secara aktif pada kegiatan pengabdian tersebut.

1) Pelatihan dalam Kelas: Melalui Inclass Training ini akan dilakukan proses peralihan pembelajaran (transfer of learning) antara pelatih dengan para peserta pelatihan atau 
di antara sesama peserta pelatihan sendiri. Demikian itu disebabkan bahwa pola yang digunakan di sini adalah pola pembelajaran orang dewasa (adult education) yang berlangsung dalam semangat kebersamaan dan kesetaraan, yang dalam hal ini antara pelatih dan peserta. Inclass Training ini dilaksanakan sebanyak 1 (satu) kali dalam kegiatan Pengabdian kepada Masyarakat ini. Dengan demikian, inilah inti dari Pelatihan ini.

2) Fieldwork: Dalam tahapan ini para peserta diwajibkan untuk menyempurnakan model karya media yang telah disusun ketika mengikuti inclass training dan kemudian mengaplikasikannya di lingkungan sekolah masing-masing. Dalam pelaksanaannya, tim monitoring dan evaluasi akan dibentuk oleh panitia untuk secara langsung memonitor dan mengevaluasi pelaksanaan proyek lapangan tersebut. Nantinya, kegiatan ini berlangsung terus hingga kemudian diadakan Seminar Hasil Fieldwork.

3) Pendampingan (Asistensi): Kegiatan pendampingan ini akan berlangsung selama fieldwork ada. Satu kali pendampingan dilaksanakan selama 2 hari. Dalam pendampingan ini para peserta membawa permasalahan-permasalahan yang mereka identifikasi dari hasil mempraktekkan pengetahuan teoretik yang pernah diperolehnya pada tahap Inclass Training sebelumnya.

Kegiatan ini terutama dimaksudkan untuk meningkatkan daya apresiasi terhadap pengetahuan berhubungan dengan kualifikasi ideal seorang tenaga pemberdaya masyarakat (empowering generator). Di lapangan, mereka diharapkan dapat memadukan antara konsep ideal dengan tuntutan kenyataan, sehingga dengan cara demikian, mereka akan dapat merumuskan pola pemberdayaan yang realistik sesuai dengan 
tuntutan setempat. Dalam setiap kegiatan pendampingan, para peserta di dalam kelas dipandu oleh seorang fasilitator dan seorang narasumber untuk membantu memecahkan masalah-masalah yang dibawa para pemberdaya dari masyarakatnya masing-masing.

Adapun sasaran yang dituju dalam pengabdian berupa pelatihan ini adalah kelompok masyarakat pembelajar, yaitu ustadz/ah dan santri dari sebuah pesantren di Garut. Pesantren tersebut, yaitu Pesantren Persatuan Islam No. 97 berada di Desa Cikandang, Kecamatan Cikajang, Kabupaten Garut. Kondisi masyarakat yang berada di perdesaan membuat pihak pesantren sendiri seringkali kebingungan menghadapi kebanyakan anak didik yang orang tuanya tidak mampu membayar biaya pembelajaran, termasuk sarana dan prasarana pembelajaran. Dari segi waktu, pengabdian ini telah dilaksanakan selama 6 (enam) bulan, dimulai pada bulan Juni hingga Desember 2019.

Adapun pengumpulan data sebelum acara pelatihan bisnis online tersebut dilakukan dengan dua cara. Yaitu, angket untuk data yang bersifat pokok dan observasi dan wawancara untuk data sekunder. Keseluruhan teknik itu adalah observasi, wawancara, dan studi dokumentasi. Observasi dilakukan ketika para peneliti terjun langsung ke lokasi penelitian yaitu mengadakan eksplorasi dan pengamatan terhadap obyek penelitian, yaitu masyarakat perdesaan di Cikajang, Kab. Garut. Sedangkan wawancara dilakukan sebagai upaya perolehan data dengan cara wawancara mendalam kepada aparat pemerintah, tokoh masyarakat, tokoh adat, dan lain-lain. Terakhir, studi dokumentasi dilakukan untuk mengumpulkan bahan-bahan berupa tulisan-tulisan yang berhubungan dengan permasalahan pengabdian yang 
kemudian dikorelasikan dengan hasil wawancara yang dilakukan. Studi dokumentasi ini juga dilakukan dengan menggambarkan riwayat pendidikan bisnis di tingkat masyarakat.

Sementara itu, validitas dan reliabilitas atas penelitian ini dilakukan dalam dengan cara (Creswell, 2002):

1) Triangulasi data dan sumber, data yang telah terkumpul melalui wawancara dari berbagai sumber informan yang berbeda baik dari kelompok aparatur pemerintah, masyarakat, kelompok kepentingan, dan pakar yang memahami masalah penelitian. Triangulasi juga dilakukan melalui berbagai pengamatan, dan analisis dokumen sehingga akan ditelaah pola keterhubungannya.

2) Pemeriksaan oleh anggota atau informan (member check) yang berperan sebagai pemeriksa sepanjang proses analisis untuk menggambarkan kejujuran data yang diberikan.

3) Pengamatan jangka panjang dan berulang di lokasi penelitian.

4) Pemeriksaan oleh rekan sejawat.

Analisis data yang digunakan adalah analisis data deskriptif, secara umum berupa reduksi data, penyajian data dan penarikan kesimpulan atau verifikasi data. Semua langkah tersebut dilakukan secara bersamaan semenjak di tempat penelitian hingga proses akhir penyusunan laporan seperti yang disarankan oleh Miles dan Huberman (1994). 


\section{HASIL DAN PEMBAHASAN}

\section{Gambaran Studi Kasus}

Nama pesantren yang dijadikan tempat pelatihan inkubasi bisnis online adalah: Pesantren Persatuan Islam 97 Simpang Cikajang. Pesantren ini beralamat di: Jl. Raya Simpang Cikajang Km. 93 Cikajang Garut. Luas lahan pesantren ini adalah: 11.000 m2 dengan luas bangunan: 3500 m2. Didirikan pada tahun 1989 oleh seorang dokter, yaitu dr. Musthofa, pesantren itu kini dipimpin oleh Al Ustadz Mohamad Ramdan, M.Ag., seorang alumni UIN SGD Bandung.

Pesantren ini sudah mempunyai beberapa satuan lembaga pendidikan, yaitu dari tingkat taman kanak-kanak (Raudhatul Athfal/RA) hingga tingkat Sekolah Menengah Atas (Mu'allimin). Berikut addalah daftar satuan lembaga pendidikan tersebut dengan pemimpin hariannya:

Tabel 1. Daftar Pemimpin Harian di Pesantren Persis 97 Cikajang
a. Pimpinan Pondok
: Ust Pribadi Zakiah
b. Raudlatul Athfal
: Lilis Gusdini, S.Pd
c. Madrasah Diniyah
: Enung Nursa'diah
d. SDIT
: Ai Sa'adah, S.Ag
e. Tsanawiyah
: Ust. Jajang Koswara, S.Ag.
f. Mu'allimin
: Ust. Anang Sumina, S.Pd
Sumber: Dok. Pesantren Persis No. 97 Cikajang, Garut, 2019.

Untuk membina seluruh satuan sekolah di atas, ada 42 guru (ustadz/ah) baik yang mukim di dekat pesantren maupun yang pulang-pergi ke kota Garut. Selain mengajar, para guru itu pun berperan sebagai tenaga kependidikan dan pembina santri. Hampir semua ustadz/ah adalah sarjana, terutama sarjana pendidikan. Berikut adalah daftar nama para pengajar tersebut: 
Tabel 2. Daftar Nama Guru di Pesantren Persis 97 Cikajang

\begin{tabular}{|c|c|c|c|}
\hline NO & Nama & JABATAN & TEMPAT TUGAS \\
\hline 1 & Mohamad Ramdan, M.Ag & Pimpinan Pesantren & Pesantren \\
\hline 2 & Anang Sumina, S.Pd. & Mudir Mu'allimin & Mu'allimin \\
\hline 3 & Abdurahman, S.Pd.I & Guru & Mu'allimin \\
\hline 4 & Jajang Ruhiat, S.Pd.I & Guru & Mu'allimin \\
\hline 5 & Rustandi, S.Pd.I & Guru & Mu'allimin \\
\hline 6 & Rukman Sutarman, S.Pd & Guru & Mu'allimin \\
\hline 7 & H. As. Abdurrahman & Guru & Mu'allimin \\
\hline 8 & Asep Dania, S.Pd & Guru & Mu'allimin \\
\hline 9 & Gun Gun Sukma Gunadi & Guru & Mu'allimin \\
\hline 10 & Kusmana, S.E & Guru & Mu'allimin \\
\hline 11 & Hadi M. Anhar & Guru & Mu'allimin \\
\hline 12 & Rini Darliani, S.Pd & Guru & Mu'allimin \\
\hline 13 & Hudman Saebani & TU & Mu'allimin \\
\hline 14 & Musonip, S.Pd.I & Guru & MTs/Mu'allimin \\
\hline 15 & D. Abdul Majid, S.Pd.I & Guru & MTs/Mu'allimin \\
\hline 16 & Tuti Maryati, S.Pd & Guru/Bendahara & MTs/Mu'allimin \\
\hline 17 & Amin Mubarok & Guru & MTs/Mu'allimin \\
\hline 18 & Pribadi Zakiyah, S.Pd.I & Pimpinan Pondok & MTs/Mu'allimin \\
\hline 19 & Ida Laela, S.Pd.I & Guru & MTs \\
\hline 20 & Jajang Koswara, S.Ag & Mudir Tsanawiyyah & MTs \\
\hline 21 & Siti Aisah, S.Th.I & Guru & MTs \\
\hline 22 & Aan Nurhasanah, S.Ag & Guru/Bendahara & MTs \\
\hline 23 & Zenal, S.Pd & Guru/TU & MTs \\
\hline 24 & Ahmad Ginanjar & TU & MTs \\
\hline
\end{tabular}




\begin{tabular}{|l|l|l|l|}
\hline 25 & Yesi Anis Fitria, S.Pd & Guru & MTs \\
\hline 26 & Elmi Siti Nurbaeti & Guru & RA \\
\hline 27 & Lilis Gusdini, S.Pd & Mudir RA & RA \\
\hline 28 & Reni Anggraeni & Guru & RA \\
\hline 29 & Hilda & Guru & RA \\
\hline 30 & Ranis & Guru & SDIT \\
\hline 31 & Ai Sa'adah, S.Ag. & Mudir SDIT & SDIT \\
\hline 32 & Lilis Siti Rohmah, S.Pd.I & Guru & SDIT \\
\hline 33 & Denis Juariyah, S.Pd.I & Guru & SDIT \\
\hline 34 & Imas Masrifah S.Pd. & Guru & SDIT \\
\hline 35 & Sadam Mardiansyah, S.Pd. & Guru & SDIT \\
\hline 36 & Dewi Sulastri, S.Pd.I & Guru & SDIT \\
\hline 37 & Syarah Arianti Lukman, S.Pd. & Guru & SDIT \\
\hline 38 & Ai Siti Rodiah, S.Pd.I & Guru & SDIT \\
\hline 39 & Isman Pratama, S.Pd & Guru & SDIT \\
\hline 40 & Enung Nurs'adiah & Gudir Diniyyah & MD \\
\hline 41 & Annisa & Yesi Anggraeni & Guru \\
\hline 42 & Sum & \\
\hline
\end{tabular}

Sumber: Dok. Pesantren Persis No. 97 Cikajang, Garut, 2019.

Selain para ustadz/ah tersebut di atas, ada beberapa orang yang bertugas sebagai pelengkap keperluan keberadaan pesantren seperti seorang satpam, petugas kebersihan, dan petugas dapur. Semua orang yang bertugas seperti itu tinggal di pesantren dan di dekat pesantren. 
Adapun santri yang bersekolah di Pesantren Persis No. 97 itu adalah mereka yang berada/tinggal di sekitar kompleks pesantren. Selain itu, ada pula yang tinggal di asrama. Berikut adalah rincian jumlah santri per unit sekolah:

Tabel 3. Jumlah Santri per Unit Sekolah di Pesantren Persis 97 Cikajang

\begin{tabular}{|l|l|l|l|l|}
\hline NO & JENJANG & LAKI-LAKI & PEREMPUAN & JUMLAH \\
\hline 1. & Mu'allimin & 37 & 40 & 76 \\
\hline 2. & Tsanawiyyah & 50 & 60 & 110 \\
\hline 3. & SDIT & 117 & 101 & 218 \\
\hline 4. & RA & 8 & 13 & 21 \\
\hline 5. & MD & 20 & 30 & 50 \\
\hline 6. & Asrama & 15 & 12 & 27 \\
\hline \multicolumn{2}{|l|}{ Jumlah Total } & 247 & 256 & 502 \\
\hline
\end{tabular}

Sumber: Dok. Pesantren Persis No. 97 Cikajang, Garut, 2019.

Keadaan jumlah santri yang cukup banyak untuk pendidikan yang ada di perdesaan, dapat menjadi rational jika ada upaya-upaya untuk membangkitkan para santri tersebut untuk lebih terlibat dalam bisnis online. Demikian agar para santri tersebut menjadi lebih berdikari.

\section{Urgensi Pelatihan Bisnis Online}

Rahman (2011: 72) memandang masyarakat sebagai kesatuan-kesatuan atau himpunan manusia yang hidup bersama, oleh karena itu adanya hubungan timbal balik saling mempengaruhi dan juga kesadaran untuk saling tolong menolong diantara anggotanya dan memungkinkan individu atau kelompok untuk berubah sesuai situasi dan kondisi yang ada pada dirinya atau luar dirinya pada saat berinteraksi. 
Pendapat George Herbert Mead (Otnes, 2017) mengenai konsep diri (self) menganalisis tindakan santri sebagai pelaku kreatif memiliki ketergantungannya dengan target seni (masyarakat) dengan ketertarikan yang sama di bidang fashion, konsep diri tersebut akan muncul jika ia berinteraksi dengan orang yang dapat memahami arti makna dari karyanya.

Dalam hal lain ketika santri hendak melakukan pengenalan karya dan mengadakan kolaborasi dengan pelaku lain di masyarakat, mereka melakukannya di ruang terbuka yang terdapat berbagai aktivitas masyarakat. Tentu ini membuat orang hanya lalu lalang tanpa ketertarikan sama sekali atau bahkan memperhatikan penjelasan mereka, sehingga konsentrasi mereka pun terpecah oleh kegiatan lainnya yang dilakukan di tempat sama. Mead (Otnes, 2017) menyampaikan bahwa kita akan menemui beraneka ragam reaksi sosial dari orang yang memiliki latar pemikiran berbeda, membuatnya kehilangan arah dalam menyampaikan maksud dan tujuan.

Dari penuturan salah seorang peserta berdasarkan wawancara, FM menuturkan akan kesulitannya untuk mencari mentor belajar yang tepat guna meraih tujuannya sebagai pelaku kreatif. FM menyampaikan bahwa ia seringkali belajar otodidak di rumah tentang membuat suatu konten kreatif, sehingga informasi yang didapatkannya hanya seadanya. Selain dari internet dan buku bacaan tentang kepenulisan, ia juga pernah mengikuti suatu forum pelatihan usaha, hanya saja tidak bertahan lama karena lingkungan yang kurang produktif dan penyampaiannya tidak mendalam (Wawancara dengan FM, santri, 19 September 2019).

Berdasarkan wawancara dengan AG selaku santri, juga sebagai peserta pelatihan, terdapat kesulitan untuk mengikuti kompetisi bisnis online. Diperlukan 
adanya produk yang kualitasnya bagus dan harganya murah (Wawancara dengan FM, santri, 19 September 2019).

Menurut penuturan FM dan AG mengenai kesulitan mereka dalam akses belajar tentang seni dan kreativitas untuk membuat bisnis online yang menarik, terdapat beberapa kendala dari mulai informasi yang kurang, alat bersifat seadanya dan tidak adanya teman belajar yang bertujuan untuk menggali kemampuan lebih dalam. Mereka hanya bisa mengandalkan fasilitas sehari-hari melalui internet yang rata-rata memberikan gambaran dasar saja. Mereka harus berusaha memahami maksud dari sebuah pembelajaran yang didapat tanpa adanya mentor untuk mencari solusi, keterbatasan ruang dan waktu juga membuat kinerja mereka berkurang. Bagaimana mereka dapat membuat suatu produk yang dapat laku di pasaran, kerap menjadi masalah utama para peserta saat ingin memulai karir mereka di bisnis ini.

Dari beberapa poin diatas, penulis mengetahui dari informasi bahwa selama ini para santri maupun masyarakat desa menemui kesulitan untuk saling berhubungan satu sama lain lewat interaksi yang mendalam dalam bidang bisnis. Kondisi tersebut disebabkan karena beberapa hal: Pertama, mereka kekurangan audience atau target bisnis, sehingga iklan yang mereka sampaikan tidak tersalur dengan baik. Kedua, sarana dan fasilitas kurang memadai sehingga mereka harus bisa mencari suasana kondusif dan mudah diakses. Ketiga, kendala biaya menjadi hal sensitif di kalangan masyarakat, karena sebagian pemula cukup keberatan jika ingin mulai belajar dengan patokan biaya cukup tinggi. Dari sebuah brosur penulis menemukan informasi mengenai biaya untuk mengikuti kerajinan tangan yang harus dikeluarkan sampai 
ratusan ribu berkisar 300-600 ribu rupiah. Tentu hal itu cukup mempersulit masyarakat desa yang notabene, bukan tempat beredarnya uang.

Setelah mengetahui interaksi yang terjadi sebelum adanya Lembaga Penelitian dan Pengabdian kepada Masyarakat (LP2M) UIN SGD Bandung sebagai pihak yang dapat membantu, maka permasalahan tersebut diringankan dengan adanya pelatihan dan sumber informasi dari pihak LP2M. Kendala dan kekurangan yang dirasakan masyarakat dapat dimudahkan dengan terjunnya lembaga perguruan tinggi ini ke masyarakat. Kegiatan yang berada di dalam LP2M mencakup segala hal yang berhubungan dengan bisnis online sehingga dirasakan manfaatnya oleh santri dan juga masyarakat. Menurut pengalaman ZS yang sudah menjalani 2 hari kegiatan berturut-turut, kegiatan pelatihan LP2M ini sangat berguna. ZS bertekad menjadi desainer dan bahkan berniat melakukan pameran seni untuk busananya serta fashion show dan lainnya (ZS, santri, wawancara 19 September 2019).

Dalam kegiatan pengabdian dosen ini, pola interaksi yang dilakukan antar santri dan peserta bisa lebih jelas tersampaikan. Di sini, interaksi dengan masyarakat atau santri menjadi maksimal karena bisa dilakukan face to face dengan melakukan pelatihan atau acara tanya jawab, sehingga informasi yang didapat bisa diterima dengan baik oleh masyarakat pemula untuk mengenal bidang sektor kreatifnya. Selain dengan para santri, hubungan interaktif juga bisa dilakukan dengan para pemula lainnya dari masyarakat, sehingga mengubahnya menjadi pola kerja tim dalam membuat suatu karya (ZS, santri, wawancara 19 September 2019). Dalam teori interaksi simbolik, tindakan dan perkataan yang dilakukan pelaku memiliki makna tentang sebuah karya 
pemikiran, jadi tindakan diambilnya sebagai bentuk ekspresi dari hasil pemikiran pelaku (individu) pada orang lain.

Hubungan yang terjalin antar sesama peserta pelatihan dapat menjadi suatu kolaborasi dalam membuat karya, dengan melakukan kerja sama memecahkan permasalahan yang tidak bisa ditangani, hingga ikut perkumpulan komunitas di setiap kesempatan. Sehingga muncul motivasi bahwa mereka belajar bersama, bukan bersaing. Semakin banyak anggota yang saling mengayomi membuat santri bisa menyalurkan bakatnya kepada orang lain, membantu mereka yang awalnya tidak tahu menjadi ingin tahu lebih dalam, dengan rutin menjalani minat yang sama, informasi yang mereka dapatkan pun akan lebih luas dan dapat memanfaatkan waktu semaksimal mungkin untuk belajar dan berinteraksi. Inilah yang menjadi tujuan dari turunnya dosen kepada masyarakat, yaitu membentuk proses sosial asosiatif berupa kerjasama dari para pelaku kreatif dengan masyarakat.

AG menjelaskan perbedaan ketika ia belajar otodidak sendiri di rumah dengan belajar bersama dengan pihak Lembaga Penelitian dan Pengabdian kepada Masyarakat (LP2M) UIN SGD Bandung. AG mengatakan perbedaan yang cukup terasa jika belajar di rumah ada hal yang tidak ia mengerti atau masalah tidak terpecahkan, ia harus mencari solusinya sendiri, terkadang itu membuatnya kewalahan karena bukan hanya waktu yang terbuang tapi juga informasi sempit yang ia andalkan dari internet (AG, wawancara 19 September 2019).

Masyarakat juga mendukung pelatihan itu supaya membawakan kemajuan dan berkembang dengan adanya sarana dan fasilitas dari pemerintah Kabupaten Garut, sehingga bisa terus berkarya dan memperoleh pengakuan atas kreativitas yang mereka 
ciptakan. Industri kreatif sebagai daya dukung terhadap peningkatan citra dan menumbuhkan kreativitas individu memberi dampak sosial positif dalam kehidupan bermasyarakat (Moelyono, 2010).

Dari pelatihan tersebut, pihak LP2M memahami perlunya program workshop yang berbeda-beda sub sektor sehingga ketika peminat yang belajar fotografi ketika melihat pameran fashion akan tertarik dan memanfaatkan untuk menjadikan obyek foto, hal ini menjadi hubungan mutualisme antara masyarakat dan santri, maka samasama bekerja sama, dari pernyataan yang telah disampaikan oleh narasumber kita mengetahui bahwa interaksi yang terdapat dalam ruang lingkup LP2M memiliki dampak positif karena adanya hubungan asosiatif yaitu kerja sama (cooperation). Bentuk ini sebagai perkembangan reaksi-reaksi yang sama terhadap berbagai peristiwa atau masalah yang dihadapi dalam kondisi seseorang. Munculnya kelebihan untuk melakukan sosialisasi yang berpengaruh pada interaksi antar kelompok dan juga antar individu atau kelompok dengan individu di lingkungan masyarakat.

Dalam penjelasan tersebut dapat kita ketahui beberapa sumber kendala yang ada sebelum hadirnya LP2M dan kendala tersebut dapat diatasi dengan kehadiran ini. Pertama, para santri dapat menjaring audience yang lebih tertarget dan berkeinginan kuat untuk belajar, ini menjadi faktor dasar para pelaku kreatif untuk menyatukan inovasi dan kreativitas mereka yang ada dalam ide santri pemula. Kedua, adanya pengolaan sarana dan fasilitas untuk para pelaku kreatif yang memadai, karena para santri dapat bekerja sama dan saling meminjam alat serta saling berbagai pengetahuan. 
Reaksi timbulnya interaksi sosial datang dari hubungan timbal balik antara individu dengan individu maupun individu dengan kelompok. Di kehidupan sosial akan terlihat berbagai bentuk pergaulan seseorang baik dalam bentuk kerja sama maupun konflik, tentunya hal tersebut memiliki beberapa tujuan seseorang dalam berkomunikasi. Dalam hal ini ada penyampaikan mengenai faktor pendukung adanya interaksi antara pihak peruguruan tinggi dengan santri dan masyarakat tentang bisnis online.

\section{Ketertarikan Peserta dengan Sektor Kreatif}

Berdasarkan informasi dan pengamatan penulis, pendukung adanya interaksi tersebut adalah ketertarikan peserta dalam sektor kreatif, mereka menyatakan adanya rasa ingin tahu untuk belajar dalam kegiatan atau event yang dilakukan oleh para pelaku kreatif. Kebanyakan dari mereka adalah orang yang ingin melatih kemampuannya di bidang tersebut, karena mereka sudah mengenal pondasi dari masing-masing sektor, sehingga yang ingin mereka tambahkan adalah memperdalam skill dan menemukan inovasi baru dalam sektor tersebut. Ditambah kegiatan yang diadakan tidak dipungut biaya dan dilakukan secara intens, sehingga mereka tidak akan menyia-nyiakan kesempatan tersebut. Ketika seseorang tertarik akan suatu hal, maka dengan sendirinya mencari tahu mengenai hal tersebut. Dalam penyataan Mead mengenai interaksi sosial yang melibatkan aktor adalah proses saling mempengaruhi.

Pada hal ini bisa disebut sebagai proses pertukaran memberi dan menerima, artinya seorang individu yang berinteraksi memiliki proses saling menguntungkan satu sama lain. Itu karena dalam masing-masing sektor kreatif dijadikan sebagai ajang untuk belajar, dilakukan pada saat mengadakan event. Akibatnya berdampak pada 
terpengaruhnya minat untuk menelusuri kegiatan kreatif tersebut, masyarakat menjadi peserta kreatif tingkat pemula yang mencoba berpartisipasi dalam mengikuti sebuah pelatihan atau pameran. Mereka memiliki visi dan misi sendiri ketika akan mengikuti acara tersebut, ada sebuah rangsangan, pengaruh atau stimulus yang diberikan sehingga membuahkan keinginan untuk di sampaikan lewat sebuah forum diskusi yang diadakan santri. Seperti penuturan FM sebagai seorang penulis dan content creator perfilman dalam sebuah wawancara mengungkapkan ketertarikannya mengikuti bisnis online untuk produk-produk perfilman. Dia mengatakan, "Karena punya ambisi pengen jadi film maker, sangat tertarik banget sampai pengen banget bikin film seperti di bioskop, tujuannya karena banyak sekali orang yang berdakwah (menyampaikan pesan) dari film, contohlah ayat-ayat cinta itu berisi dakwah dan lainnya.” (FM, wawancara 19 September 2019).

Sehingga selain untuk memenuhi keingintahuan di bidang seni dan kreativitas, para profesional dan pemula dapat saling membantu, melengkapi dari sisi kekurangannya, maka obsesi anak muda untuk memenuhi karir dan impiannya bisa disalurkan melalui partisipasinya lewat sebuah forum sharing. Pada dasarnya kesempatan awal menjadi jalan terbuka bagi santri pemula untuk menemukan solusi atas kekurangan mereka dalam menekuni tujuan atau pencapaiannya di industri kreatif.

Salah satunya dengan adanya beberapa keuntungan dalam sebuah forum sektor kreatif dengan diikuti para peserta, hal ini dapat berupa sarana sharing antar pelaku kreatif tentang skill tertentu yang harus mereka asah. Forum sharing diperuntukkan kepada santri dan peserta berupa publikasi informasi, jadi didalamnya tidak terdapat 
batas informasi pribadi tetapi dapat dikonsumsi massal oleh para pelaku kreatif. Maka bertukar pikiran para peserta dilakukan antara individu dengan kelompok, kelompok disini merupakan sebuah forum yang telah disesuai dengan penyaringan dan penyeleksian informasi mana yang dapat dipahami pemula.

Melalui seorang santri profesional berpengalaman dan telah terjun terlebih dahulu, memudahkan mereka untuk berinteraksi langsung dan menjawab semua pertanyaan mereka. Pendidikan seorang profesional merupakan proses esensial menurut pandangan Mead karena aktor (individu) tidak menemukan jati diri dan belum menjadi anggota komunitas sesungguhnya hingga mereka mampu menanggapi diri mereka sendiri seperti yang dilakukan komunitas terdahulu, sehingga perlu mengambil tindakan yang menginternalisasikan sikap bersama komunitas (dalam hal ini santri senior dan ustadz/ah).

Walaupun pertemuan tersebut hanya berdurasi singkat, tetapi mereka bisa merangkum seluruh informasi dari pembicara untuk mengembangkan karya mereka. Adapun dalam event atau kegiatan yang diselenggarakan bertahap dalam membahas suatu sektor, dimulai dari informasi dasar melalui pengenalan dari informan kemudian pengenalan masing-masing peserta, kemudian pembukaan dengan memperlihatkan hasil karya, selanjutnya penyampaian proses dari suatu karya tersebut diciptakan, dan diakhir acara biasanya mereka melakukan ajakan kembali untuk melakukan pertemuan berikutnya berupa teknik (praktek) kepada peserta, namun ada juga yang hanya memberikan kesimpulan saja dan juga pemberian alat dan bahan untuk dipraktekkan sendiri di rumah. 
Seperti FM yang menyampaikan motivasinya yang ingin mencoba terus menghasilkan karya setelah berdiskusi dengan narasumber. Narasumber memberikan solusi tentang pembuatan sebuah alus cerita yang baik dalam sebuah iklan bisnis online. Hal tersebut membuat FM sebagai penulis pemula memiliki ide lain untuk menghasilkan sebuah cerita hasil recovery (daur ulang) yang diberikan intrik khusus sehingga bisa difilmkan. Karena sebelumnya ia pernah membuat cerita tentang bertema religi yang membuatnya gagal dalam kompetisi, kini dirinya memiliki pemikiran lain mengenai karya baru yang diambil dari cerita lama tapi lebih fresh dan unik (Wawancara dengan FM tanggal 19 September 2019).

Komunikasi terjalin antara santri dan peserta merupakan jenis interaksi langsung yang memberi informasi tanpa melalui perantara sehingga memunculkan tindakan. Dalam interaksi simbolik, tindakan sosial adalah tindakan dimana individu bertindak dengan orang lain dalam pikiran, dengan kata lain dalam melakukan tindakan seorang aktor (individu) mencoba menaksir perilakunya terhadap orang lain yang terlibat (Ritzer, 2014).

Pelatihan dilangsungkan sebagai bukti para santri untuk menghasilkan karya bukan hanya teori, teori hanya sebagai informasi dasar sedangkan praktek merupakan wujud dari tindakan. Peserta yang mengikuti bisnis online sebagai sebuah karya tulis, mereka akan membuat suatu cerita yang nanti mendapat penilaian atau tinjauan dari santri, selanjutnya akan diseleksi untuk dijadikan karya dalam wujud perfilman, content video atau artikel untuk sebuah produk. Dari proses tersebut kita dapat mengetahui, alur jalannya pembuatan karya tidaklah mudah maka dengan adanya bantuan dari pelaku seni, motivasi pribadi, dan juga dorongan dari pihak-pihak terkait 
diharapkan dapat membantu melancarkan penyeluran minat dan bakat dari masingmasing peserta.

Oleh sebab itu, pembelajaran disajikan dengan memberikan informasi sekaligus praktek langsung sebagai akibat dari tindakan aktor (dalam hal ini santri atau peserta). Karena sebuah teori hanya bentuk dari interaksi pemikiran sedangkan tindakan adalah sebagai aksi atas dasar pemikiran itu.

Interaksi yang dibagikan santri dilakukan melalui sebuah simbol, berdasarkan pertunjukkan karya seni yang mereka lakukan, didalam pengenalannya para santri mengapresiasikan hasil kerja keras mereka dalam industri kreatif dengan memamerkan karya yang telah diakui masyarakat. Hal ini akhirnya menambah rasa ketertarikan para pemula untuk mengakui keindahan dan hasil seni dari tangan para santri.

Mereka yang tertarik di dunia kreatif mengaku pada awalnya melakukan kebiasaan kecil di sektor kreatif, sehingga lama kelamaan mereka tertarik menyalurkan seluruh passion-nya di bidang ini, seperti ungkapan AG salah seorang animator pemula yang ingin melakukan pencarian keuntungan (monetizing) melalui bisnis online. AG menyatakan, "Keinginan saya menyukai animasi karena dari dulu suka gambar aja, awalnya sedikit tertarik kalau ada yang hubungan sama animasianimasi gitu, akhinya coba masuk ke bidang ini buat cari tahu bakat sendiri." (AG, wawancara tanggal 16 September 2019.

Lembaga Penelitian dan Pengabdian kepada Masyarakat (LP2M) tidak hanya sebagai fasilitator yang menciptakan ruang dan tempat, tetapi juga berperan dalam mempersatukan AG dengan para profesional yang memberikan pelatihan dan 
inspirasi bagi dirinya dan orang lain. LP2M mempertemukan pemula dan profesional untuk dapat menggunakan akses yang tersedia bagi para santri dalam mempelajari informasi baru.

Ikatan antara para pelaku kreatif berawal dari cara mereka untuk memperluas jaringan sosial, yang demikian itu disadari bahwa mereka adalah orang-orang yang berasal dari minat sama, rasa ketertarikan dan tujuan sama yakni penikmat industri kreatif maka tidak sulit untuk menemukan target masyarakat yang bersedia bergabung dengan para santri. Rasa keingintahuan yang kuat ini menjadikan salah satu alasan para santri memperkenalkan karyanya di berbagai sarana media atau lewat komunitas di masing-masing sektor kreatif.

Jika menjaring para peserta sebagian santri memanfaatkan media sosial online sebagai cara promosi singkat memperkenalkan sektor mereka, seperti instagram, twitter, facebook yang digunakan untuk menampilkan karya dan event-event yang sedang diselenggarakan, setelah itu mereka mencantumkan kontak person seperti line atau nomer whatsapp, gunanya untuk melakukan pendaftaran peserta jika ada yang berminat mengikuti rangkaian kegiatan mereka atau juga bisa sebagai kolom bertanya secara pribadi dengan santri, mengenai permasalahan mereka, inspirasi maupun bertukar pendapat. Selain lewat online mereka juga menjaring lewat media offline dengan berbagai caranya sendiri.

Dalam lingkungan sosial masyarakat setiap orang memiliki peran masing-masing, dalang lingkup industri kreatif santri atau pelaku seni merupakan unit komunitas yang memiliki peran untuk menemukan bakat baru di dunia kreatif, santri terintegrasi atas dasar kesepakatan dari para pesertanya akan menanamkan suatu nilai jual yang 
mereka pamerkan dengan mengadakan lomba atau event untuk menarik perhatian para produsen baru. Terintegrasi dalam hal ini merupakan penyatuan minat peserta dari masyarakat dengan santri, jadi para pemula dapat melebur menjadi satu dalam lingkungan industri ini. Cara tersebut dilakukan agar lahir santri-santri muda berbakat yang bisa menyalurkan kelebihan milik mereka, sekaligus para santri senior membantu bibit-bibit baru tersebut agar percaya diri dan mau menonjolkan karyanya.

Pengenalan seni pada santri pemula dimulai ketika peserta mendaftarkan diri mereka lewat acara yang di selenggarakan santri, kemudian mereka akan di fasilitasi dengan pemberian alat pendukung selama proses pembelajaran. Mereka akan mengenal dasar penggunaan dulu. Menurut AG sebelum ia kenal cara menggambar dengan teknik tertentu, dirinya akan diberikan pengarahan oleh instruktur mengenai pola dasar dalam animasi lalu akan diarahkan pada penggambaran melalui media kanvas setelah itu baru lewat design grafik di komputer. Dari bentuk hubungan tersebut, terdapat sebuah proses interaksi lewat masukan pikiran dari cara-cara santri memberikan pengarahan pada peserta, ini dilakukan supaya adanya kesinambungan antara jalan pemikiran dan ide yang saling terkait satu sama lain, sehingga tidak menimbulkan kesalahpahaman.

Sedangkan, dalam bentuk proses asosiatif bentuk-bentuk interaksi sosial atas dasar bahwa segala macam bentuk interaksi tersebut dapat dikembalikan dengan perolehan kerja sama. Oleh sebab itu, sebagian santri tak sulit mencari bakat baru karena telah bekerja sama dengan pihak lain untuk menyalurkan bakatnya supaya mau maju, kerjasama dengan tempat khusus membuat mereka bisa berkomunikasi 
langsung dengan peserta baru yang memiliki keinginan kuat untuk menonjolkan bakatnya.

Dari hasil yang telah diungkap LR maka dapat terlihat, bahwa interaksi yang dimulai berawal dari hasil afiliansi dan kerja sama sebelumnya. Sebagai salah satu memperoleh partisipasi aktif, mereka memiliki beberapa relasi yang sudah terjun di bidang serupa. Sehingga ketika mereka mengadakan kegiatan, para santri ini tinggal mempromosikan acara-acara pelatihan lewat sanggar-sanggar yang sudah mengenal mereka (Wawancara dengan LR, 16 September 2019).

Dari penjelasan itu dapat diambil kesimpulan mengenai beberapa cara para santri dalam menjaring orang-orang berbakat, yaitu dengan aktivitas di media sosial yang dapat diikut para peserta, pendekatan yang dilakukan sebelum peserta ikut terjun langsung dalam kegiatan santri, hal tersebut dilakukan agar mengarahkan mereka ke lingkungan sektor kreatif. Melakukan touring atau kompetisi antar daerah tertentu, dimaksudkan agar santri mengetahui tingkatan bakat dari masing-masing peserta sehingga nantinya mereka akan dilatih sesuai dengan kemampuan yang sudah dikuasai, berbeda dengan kegiatan seminar dilakukan untuk memperkenalkan basic pada pemula, kompetisi lebih masuk ke tahap perdalaman skill masing-masing santri yang telah terjun lama dan memahami bentuk dasar. Cara selanjutnya adalah mempererat bentuk kerja sama sebelumnya, artinya mereka memang sudah mengenal satu sama lain dan membentuk sebuah aliansi sehingga ketika mengadakan kegiatan maka santri tidak perlu mempromosikannya lagi karena telah memiliki audience langganannya sendiri. 


\section{Penyampaian dan Sosialisasi yang Baik}

Sifat terbuka yang terjalin antara para pelaku kreatif membuat mereka membuka diri dalam hal sosialisasi dan pengenalan di lingkungan masyarakat. Sosialisasi langsung kepada masyarakat lewat promosi media sosial dan pameran dalam menjalin hubungan dengan banyak orang memberikan efek positif atas pesan yang disampaikan, berdasarkan penyampaian informasi dari masing-masing sub sektor mereka memiliki cara sendiri untuk menyampaikan makna lewat karyanya. Proses sosialisasi dilakukan oleh santri atau peserta baik secara sadar atau tidak secara sadar, biasanya orang-orang yang memiliki kewibawaan melakukan sosialisasi dengan tujuan tercapainya kedisiplinan pihak yang disosialisasi.

Pada perannya seorang santri memang terbuka tanpa membatasi diri mereka dalam berinteraksi dengan masyarakat awam, sosialisasi terjadi khususnya kepada para peserta sebagai santri pemula. Keterbukaan informasi menjadi kelebihan yang dimiliki santri dalam bersosialisasi sehingga ketika dilakukan secara terus menerus akan mendapatkan jalinan kuat dalam lingkungannya.

Proses jalinan sosialisasi tersebut menarik peserta (santri pemula) untuk dapat mengenal lingkungannya dengan cara bergaul dalam kelompok, dimulai dari tahap persiapan para pemula untuk belajar, lalu tahap meniru pemula dari santri profesional tentang cara mereka mengolah suatu karya kemudian tahap bertindak dengan melakukan praktek langsung setelah pengolahan informasi.

Dari pandangan George Herbert Mead, individu harus mampu mencapai keadaan di luar dirinya sendiri, sehingga untuk berbuat demikian individu pada dasarnya harus menempatkan dirinya sendiri dalam bidang pengalaman yang sama 
dengan orang lain. Tiap orang adalah bagian penting dari situasi yang dialami bersama dan tiap orang harus memerhatikan diri sendiri agar mampu bertindak rasional dalam situasi tertentu. Dalam tindak rasional ini mereka mencoba memeriksa diri sendiri secara impersonal, obyektif, dan tanpa emosi. Tetapi, orang tak dapat mengalami diri sendiri secara langsung, mereka hanya dapat melakukannya secara tak langsung melalui penempatan diri mereka sendiri dari sudut pandang orang lain itu. Dari sudut pandang demikian orang memandang dirinya sendiri dapat menjadi individu khusus atau menjadi kelompok sosial sebagai satu kesatuan. Inilah konsep diri (self) yang dimaksud Mead (Ritzer, 2014).

Seorang santri harus bisa mengakrabkan diri dengan cepat dalam menjalin sosialisasi dengan peserta. Hal ini dilakukan agar penyampaiannya dapat diterima secara jelas, rinci, dan terpapar langsung oleh pelatih. Upaya pendekatan ini mereka lakukan agar menghasilkan rasa emosional yang terbangun diantara pelaku kreatif sehingga pada akhirnya mendapatkan respon yang baik. Sosialisasi yang dibangun dengan cara mereka membagikan pengalaman dan ketertarikan dalam sektor bidang sama. Hal tersebut diungkap ZS sebagai seorang santri yang berminat pada fashion:

Sekarang lewat pelatihan ini, masyarakat udah terbuka tentang fashion jadi kita nggak terlalu susah untuk memberitahu lagi, mungkin cara mempromosikan acara kita sendiri aja dan kita cari anak-anaknya lewat media sosial karena media sosial luas banget dan menjangkau semuanya, terus kita mencoba untuk menggaet anak muda, ayo kita bisa ini ada inovasi baru dan lain-lain jadi, kita pertama dari media sosial menggaet yang kalangan muda dan mencoba menggaet dari kalangan profesional yaitu apresiator dari karya itu sendiri, jadi kita dapet dari kalangan awamnya dan dari kalangan profesionalnya. (ZS, wawancara 19 September 2019).

Bentuk sosialisasi yang disampaikan yaitu dengan penyaluran bakat melalui seminar atau pelatihan, dalam kegiatan tersebut santri memberikan ceritanya 
mengenai pengalaman mereka dalam menciptakan suatu karya, dimulai dari awal mereka merintis bakat itu sampai adanya pengakuan dari masyarakat tentang produk yang dihasilkan, semua itu membutuhkan kesabaran dan perjuangan oleh sebab itu para profesional seringkali memberika motivasi dalam pelatihan agar audience dapat terdorong kemauannya dalam berkarya tanpa takut gagal.

\section{Jalinan Kerjasama}

Adanya media ruang kreatif berpengaruh besar terhadap hubungan yang terjadi antara individu-individu pelaku kreatif dengan masyarakat, dalam hal ini muncul adanya bentuk asosiatif dalam bentuk kerja sama (cooperation). Kerja sama dapat terjadi karena di dorong oleh kesamaan tujuan atau manfaat yang akan diperoleh dalam sebuah hubungan. Charles H. Cooley memberikan gambaran tentang kerja sama dalam kehidupan sosial, bahwa kerja sama timbul jika orang menyadari mereka mempunyai kepentingan yang sama dan pada saat yang bersamaan mempunyai cukup pengetahuan dan pengendalian terhadap diri sendiri untuk memenuhi kepentingan ini melalui kerja sama. Kesadaran akan adanya kepentingan yang sama merupakan faktafakta penting dalam informasi yang berguna. Adapun proses kerja sama yang terkait antar sesama pelaku kreatif menjadikan kegiatan-kegiatan kreativitas menjadi lebih aktif. Hal ini terjadi di beberapa sub sektor yang ada, oleh karenanya muncullah ide yang menghasilkan penciptaan inovasi baru, seperti gagasan yang sebelumnya tidak ada ataupun dalam pembuatan kolaborasi penciptaan suatu karya.

Bentuk kerja sama santri ini dapat dikategorikan sebagai suatu kesatuan yang saling menguntungkan satu sama lain, interaksi sesama anggota sub sektor kreatif terjalin baik, dan ditempuh dengan sikap cooperative (kerjasama) dan bersama-sama 
dalam menyikapi masalah. Kerja sama yang ada adalah dengan melakukan beberapa kegiatan keterlibatan langsung baik itu dalam pembuatan karya, seperti kesenian, craft, musik, fotografi, dan lain sebagainya yang tentunya karya-karya tersebut masih dapat dilakukan ketertarikan peserta dalam mengelola bakatnya dalam rangka bisnis online, pada akhirnya. Hubungan dengan sesama santri juga berjalan dengan baik, saling mengenal, komunikasi aktif, dan melakukan kolaborasi.

Kerja sama timbul antar para pelaku kreatif yang menyadari bahwa mereka mempunyai kepentingan-kepentingan yang sama dan pada saat bersamaan mempunyai cukup pengetahuan dan pengendalian terhadap diri sendiri untuk memenuhi kepentingan-kepentingan karena kesadaran akan tujuan sama dan adanya organisasi merupakan fakta-fakta yang penting dalam hubungan kerja sama.

Lebih jelasnya hubungan jalinan kerjasama antar santri dan peserta dari masyarakat merupakan proses pembelajaran dan memperdalam skill di sektor tersebut. Dengan berbekal pengetahuan dasar mengenai sub sektor tertentu serta keterampilan dalam membuat karya sendiri, para peserta dapat berbaur dengan para santri dan menjadi landasan adaptasi yang dilakukan individu dalam mengikuti kegiatan agar menjadi lebih mudah dan cepat menerima informasi bidang kreatif tersebut. Kerja sama tersebut dapat berbentuk sebuah koalisi, yaitu kerja sama yang terjalin dengan menyatukan kombinasi antara pelaku kreatif dan peserta dalam mempunyai tujuan yang sama sehingga memungkinkan adanya kolaborasi. Terlepas dari apakah terdapat akibat-akibat positif atau negatif, kerja sama sebagai salah satu bentuk interaksi sosial merupakan gejala universal yang ada pada masyarakat di mana pun juga. 


\section{Sarana Pendukung}

Selain itu, faktor lainnya adalah tersedianya media penunjang yang digunakan sebagai sarana pertemuan santri dan peserta ataupun pelaku kreatif lainnya, seperti aula auditorium yang cukup luas biasanya digunakan untuk pertunjukkan karya seni, lalu ruang pameran untuk mengapresiasi hasil keterampilan, perpustakaan sebagai tempat mencari ide dari sumber dokumentasi, studio dari masing-masing sub sektor. Serta keuntungan lain ketika belajar di pesantren disediakan tempat amfiteather yang menghadap langsung pada ruang terbuka dengan area nyaman. Tidak hanya terbatas itu, terdapat beberapa spot untuk berdiskusi dan belajar di beberapa titik sehingga setiap orang tidak jenuh karena bisa berganti-ganti tempat.

Dari berbagai aktivitas kreatif digulirkan di berbagai tempat, baik oleh pemerintah, dunia bisnis maupun oleh kaum intelektual. Publikasi di media massa dan di dunia maya semakin intensif, komunitas-komunitas semakin tumbuh dan mulai saling terhubungan. Kota-kota dan daerah semakin antusias untuk menjadi kota/daerah kreatif. Lembaga Penelitian dan Pengabdian kepada Masyarakat sebagai pihak perguruan tinggi menyediakan diri sebagai milik umum, yang sedia memberi layanan untuk masyarakat.

Dengan disediakannya sarana yang beraneka ragam dan segala kegiatan, membantu para peserta menyelesaikan proyek mereka dan mencari ide, daripada hanya dilakukan di rumah atau ruang publik lain. Di sini fasilitas pesantren boleh dipakai secara gratis asal melalui prosedur manajemen terlebih dahulu.

Menurut TL, selaku pengelola layanan informasi Pemerintah Kab. Garut menegaskan, sebagai lembaga pemerintah mereka membantu berjalannya segala 
aktivitas positif yang berkaitan dengan kreativitas. Disini mereka dapat berlatih dan belajar dengan bebas tidak terbatas atau terkendala tempat. Karena berbagai sektor kreatif terkumpul ketika ada pelatihan atau event tentang sebuah sektor tertentu, misalnya fotografi seseorang bisa langsung belajar dan praktek, tidak perlu khawatir tentang biaya maupun alat, pemerintah berusaha memberi dukungan berupa peminjaman alat atau tempat secara cuma-cuma. Jika seseorang masih awam dan belum ahli, Dinas akan mengenalkan mereka kepada seseorang yang profesional sehingga dia bisa mengobrol (sharing) dengan komunitas kreatif yang ada di Kantor Dinas sekaligus praktek dengan alat dan sarana yang tersedia (Wawancara dengan TL, pegawai Dinas Kab. Garut, 19 September 2019).

Dari kemudahan akses tersebut membuat para calon santri menjadi dapat mengekpresikan kreasinya. Disini kegiatan dan pembelajaran dilakukan bersama-sama sehingga mereka diberi pengarahan dan petunjuk dalam mengasah kemampuannya, berdasarkan observasi para pelaku kreatif ini berinteraksi dengan sesamanya dengan melakukan pembelajaran langsung, juga berhubungan untuk menjalin jaringan pertemanan.

Melihat potensi ekonomi kreatif di Kabupaten Garut yang masih terus dikembangkan, melalui pengabdian perguruan tinggi ini sebagai sarana sudah cukup untuk menampung berbagai pengembangan diri dari bidang fashion, kerajinan, fotografi, desain, musik, perfilman, dan pasar seni. Maka dari itu perhatian perguruan tinggi ini diperlukan untuk menyatukan para pelaku industri kreatif yang saling berinteraksi dan menghasilkan kolaborasi, inovasi, dan kreasi dalam karya dan produk masyarakat. 


\section{Upaya Pertahanan Hubungan Sosial}

Karakter dan kepribadian merupakan dorongan secara internal yang melahirkan tingkah laku. Jika mendefinisikan kepribadian seseorang maka di situ akan ditemukan berbagai hal, diantaranya kepentingan, pemikiran, sikap, cara-cara tingkah laku, keinginan, tujuan dan sebagainya. Dalam hubungannya interaksi sosial harus memiliki mekanisme atau pola dari proses yang sedang berlangsung dalam kehidupan sosial. Pola tersebut menekankan pada aspek kebiasaan dalam terjalinnya suatu hubungan dalam kehidupan masyarakat, maka mekanisme upaya pertahanan santri dengan peserta dari masyarakat dapat terjalin dengan adanya kepentingan dan tujuan yang sama.

Sesuai wawancara, mereka melakukan beberapa cara untuk menjalin hubungan yang awet antara pelaku kreatif, salah satunya dengan mengadakan kumpul bareng yang berisikan pembahasan hasil karya mereka masing-masing. Dalam acara sharing bareng komunitas fashion, misalnya mereka mengadakannya secara rutin, para designer yang memiliki jadwal padat akan disesuaikan dengan kesenggangan mereka di waktu weekend. Dalam pertemuan tersebut, mereka tidak canggung-canggung untuk saling berinteraksi satu sama lain, terkadang mereka juga berganti topik dengan saling bercanda dan mengungkap suka citanya dalam membuat karya produk, sehingga mereka cepat akrab serta berkerja sama mengadakan kegiatan-kegiatan lainnya di luar komunitas.

Dari sinilah para santri terkumpul pada suatu komunitas dalam bidangnya masing-masing, sehingga terdapat sebuah kontinuitas yakni hubungan yang berjalan secara berkesinambungan dan sifatnya tidak sementara tapi menciptakan hubungan 
lama antar anggotanya. Itu sebabnya antar santri saling memiliki grup dalam sosial media maupun kehidupan nyata, fungsinya tak lain untuk berdiskusi dan mengadakan forum sharing dengan para senior yang sudah terjun di industri kreatif sebelumnya. Jadi santri pemula dapat melebur menjadi satu dalam suatu komunitas fashion, fotografi atau sektor kreatif lain, sehingga tidak ada sekat yang menghalangi pemula dalam proses interaksi sosial. Seperti dikatakan ZS: "Kita ada forumnya tersendiri jadi kita mencoba menjaga silaturahminya dari forum ada line grup fashion, silaturahmi dengan para senior di bidang ini dan sudah bergelut di bidang fashion yang lebih luas dan kita juga mendapat ilmunya." (ZS, wawancara 19 September 2019).

Selain menjadi silaturahmi dengan berhubungan baik secara intens, mereka juga kerap kali membuat kesan pertama yang baik ketika mengadakan acara atau kegiatan. Mereka memberikan pelayanan prima atas kepeduliannya pada event yang diselenggarakan. Interaksi yang terjalin oleh santri dengan masyarakat dalam hal ini peserta pemula adalah hubungan saling mempengaruhi satu dengan yang lainnya, bahkan dengan lingkungan sekitar, ada keuntungan antara kedua belah pihak dan menimbulkan suatu bentuk hubungan yang harmonis dan nyaman dalam pelaksanaanya, sehingga sebuah kesan pertama mereka dapat membekas dan berlanjut ke pertemuan berikutnya. Adapun hubungannya dengan saling mempengaruhi, berupaya untuk merubah pola pikir peserta melalui interaksi dengan bentuk mindset menurut Mead yang berarti jenis berpikir yang mencakup pengatasan masalah secara sadar atau komunikasi pribadi, dimana individu memikirkan tindakantindakan yang potensial lebih dulu dari pelaksanaannya dan menilainya menurut konsekuensi-konsekuensi yang dibayangkan terlebih dahulu, termasuk reaksi-reaksi 
yang mungkin muncul dari orang lain. Hal ini menuntut mereka menjadi obyek bagi mereka sendiri yakni kesadaran diri.

Kegiatan atau pelatihan menjadi tempat pertama dan utama bagi mereka para pemula untuk berkenalan, utamanya bagi mereka yang mencari tempat atau wadah untuk berbagi ilmu, informasi dan juga hobi yang sama. Kegiatan itu diadakan dengan tujuan untuk memudahkan para pemula dalam mencari sumber akurat tentang sektor yang didalami, pelatihan sebagai suatu cara bagi para pemula mengasah kreativitasnya, sifat ramah dan terbuka para pelatih itulah yang membuat pemula baru yang bergabung menjadi lebih mudah untuk beradaptasi dan bersosialisasi dengan mereka. Melalui interaksi dan intensitas pergaulan yang cukup erat di antara mereka, maka terbentuklah perasaan senasib dalam menghadapi dilema yang sama. Adapun sajian pembelajaran yang disediakan tidak hanya terkait dalam satu bidang, tetapi juga mempelajari bidang lainnya. Hal ini dilakukan untuk mengenalkan semua sektor kreatif dan mengenal ilmu yang tidak terbatas. Para anggota kreatif seperti ini memiliki perasaan saling pengertian dan memiliki jalan pikiran serupa dalam berkarya.

Dengan memberikan komunikasi yang baik dengan bertatap muka secara langsung, maka pengarahan yang akan disampaikan juga terarah dengan baik. Tentunya pertemuan ketika kegiatan itu dilakukan dibuat agar antara para santri yang sudah masuk terlebih dahulu dalam komunitas kreatif dapat mengenal lebih dekat dan mempererat tali silaturahmi para pesertanya. Kontak sosial yang terjadi ketika acara event atau pelatihan akan saling memperkenalkan diri dan melakukan $Q \& A$ dalam setiap sesi. Momen ini berdampak pada keharmonisan dalam menjalin 
hubungan dengan santri lain, sehingga bisa lebih dekat dan akrab satu sama lain. Maka support (dukung) pun akan selalu mereka dapatkan dari kerja sama dalam berbagai kesempatan acara.

Hubungan intens yang dilakukan dalam komunitas atau forum, dari perkumpulan itu mereka saling bertukar kontak dan pengenalan diri selama event berlangsung, hubungan pertemanan dilakukan antar sesama anggota yang memiliki visi dan tujuan sama dari situlah timbul rasa solidaritas saling melengkapi. Jika hubungan sesama peserta sudah terjalin dengan baik maka tugas santri adalah mengayomi mereka supaya dapat tercapai tujuan tersebut.

\section{Kontribusi Terhadap Masyarakat Desa}

Adanya partisipasi kreativitas dari para santri seperti yang ada di Pelatihan ini menguntungkan bagi masyarakat sekitar, karena mereka dapat mengasah kemampuannya sehingga hasil karya tersebut dapat dijual di pasaran. Demikian sehingga masyarakat akan dengan semangat mengikuti apabila sudah sukses. Ada kebanggaan pula di masyarakat karena karya yang tercipta di sekitar mereka dapat dijual keluar dari Cikajang (Wawancara dengan ZS, yang bercita-cita jadi fashion designer, 19 September 2019).

Jadi, kontribusi yang disampaikan ZS yakni berupa pemberian peluang kepada masyarakat untuk mengembangkan bakat dan ide, terutama bidang fashion. Ia membuat para seniman pemula tidak kehilangan jalan dan arah untuk dapat menggapai mimpi dan imajinasi mereka. Tidak hanya itu, pemerintah pun ikut andil dalam mengapresiasi sebuah nilai atau harga atas sebuah karya dengan memberi 
penghargaan atau menyalurkan bakat mereka ke kancah mancanegara (Wawancara dengan ZS, yang bercita-cita jadi fashion designer, 19 September 2019).

Pelatihan yang disediakan oleh LP2M UIN SGD Bandung membuka peluang kepada siapa saja untuk belajar serta memperkukuh rasa solidaritas antar santri dan masyarakat di Cikajang. Hal itu karena tempat awal mereka mengadakan pelatihan maupun pemberlajaran menjadi ajang untuk silaturahmi dan menambah teman baru. Keuntungan selanjutnya adalah dapat mengasah bakat dan memberi kesempatan bagi para santri untuk menghasilkan karya di mata masyarakat. Bentuk dari kontribusi yang LP2M berikan untuk masyarakat yaitu berupa akses pelatihan gratis dan intensif untuk siapa saja yang tertarik untuk berkarya dan melakukan bisnis online. Interaksi yang dilakukan ini berdasarkan kepentingan bersama maka disebut sebagai proses sosialisasi ekualitas, yakni dilakukan oleh santri-santri yang memiliki kedudukan sama. Dalam proses ini tidak ada paksaan dengan menggunakan otoritas dari pihak tertentu, melainkan untuk memasuki suatu hubungan kerja sama secara koordinatif dan kooperatif (Wawancara dengan PZ, staf pengajar, 19 September 2019).

Selain dari para dosen dan ustadz yang memberikan konstribusi berupa materi, adapula pemerintah yang siap melayani bantuan untuk mengembangkan bisnis online yang dilakukan oleh masyarakat (Wawancara dengan TL, pegawai Pemkab. Garut, 19 September 2019).

Pemaparan di atas menunjukkan bahwa beberapa pihak dapat memberikan kontribusi berupa:

(1) Keterbukaan dalam mengenalkan dan melatih bakat-bakat dari masyarakat. Tidak ada batasan untuk siapa saja yang mau belajar karena mereka akan 
bersedia menampung segala aspirasi, tidak terbatas hanya untuk santri maupun pihak pesantren tetapi seluruh lapisan masyarakat memiliki niat mau belajar, sesuai bakat yang ingin digelutinya.

(2) Dari keterbukaan tersebut, mereka kerap kali melakukan kompetisi sebagai ajang pembuktian karya yang nantinya bisa menjadi modal pertama untuk berbisnis maupun berkarir. Para santri ini membuka peluang agar masyarakat mau mandiri dan menghasilkan karya dan menjualnya sehingga dapat diakui oleh karya anak bangsa berkualitas dan mampu bersaing mengharumkan produk lokal di mata dunia.

(3) Dinas Kebudayaan dan Pariwisata Kabupaten Garut memberikan kontribusi melalui apresiasinya dengan memberikan fasilitas kepada masyarakat secara gratis untuk mengenalkan bidang seni dan kreativitas serta bekerja sama dengan pihak-pihak dari kalangan profesional seni atau produk konsumen.

(4) Sedangkan bentuk kontribusi dari para pengabdi masyarakat yakni dukungan dan bantuan pada siapa pun individu maupun kelompok yang ingin menghasilkan karyanya di segala bidang sektor kreatif, maka adanya hubungan saling membantu satu sama lain menjadikan akar kuat terjalinnya proses asosiatif (kerja sama).

(5) Dukungan pemerintah Kabupaten Garut secara umum dan pihak UIN SGD Bandung adalah dengan memberi value (nilai) terhadap karya-karya terbaik dari masyarakat, mereka kerap kali mengadakan pameran seni atau produk sebagai wujud apresiasinya. 
Dari pemaparan demikian banyak cara untuk memperoleh peluang meraih mimpi dan membuat karya. Melalui peluang ini, maka akan lahir produsen-produsen dan peserta wirausaha baru yang karyanya patut dihargai. Melalui program Pelatihan LP2M kreativitas dapat diwujudkan dan mengisi waktu luang lebih bermanfaat dari pada kegiatan anak muda yang hanya menghabiskan waktu dengan bermain-main di tempat tertentu tanpa membawa hasil.

Garut yang terkenal dengan slogan "Swiss van Java," harus ditopang dengan segala inovasi yang berkembang pesat diantara warga Garut, sehingga dapat menjadi salah satu kebanggaan tersendiri, sebagai motivasi untuk lebih meningkatkan karya dan produk serta dapat bersaing di dunia online.

\section{Faktor Penghambat}

Ada beberapa alasan mengapa bisnis online kurang berkembang di perdesaan. Di antaranya adalah:

a. Sumber daya manusia

Mayoritas masyarakat yang hidup di perdesaan telah lanjut usia sehingga kapasitasnya terbatas. Misalnya, untuk proses bisnis berbasis hewan ternak cukup sulit. Karena, masih perlunya menyewakan orang untuk mengurus hewan ternak. Karena sumber daya manusia yang belum bisa mengontrol atau pun mengawasi karena memang kurang mengetahui tentang hewan-hewan ternak untuk dimanfaatkan ke depannya. Program pelatihan masyarakat boleh jadi menjadi sebuah motivasi dan inovasi besar dalam bantu memberdayakan masyarakat. Namun, untuk saat ini program ini masih dalam tahap pengembangan (Wawancara dengan HR, Humas Pesantren Persis No. 97 Cikajang, 19 September 2019). 


\section{b. Teknologi}

Karena keterbatasan modal maka pesantren dan masyarakat perdesaan belum bisa melakukan usaha pemfasilitasan (mesin-mesin) ataupun teknologi yang mendukung dalam menjalankan teknologi operasional. Hal itu menyebabkan kegiatan operasional termasuk pembukuan masih manual. Demikian juga dalam hal otomatisasi dalam bidang bisnis online, masih kurang.

\section{c. Lokasi}

Lokasi perdesaan yang kurang strategis karena fasilitasnya, termasuk internet yang kurang memadai. Demikian karena lokasi pesantren sebagai pusat bantuan pengembangan bisnis online ini masih di lingkungan perdesaan.

d. Kesulitan dalam menentukan ciri khas keterampilan

Langkah selanjutnya dalam merealisasikan rencana awal program pelatihan ini adalah menentukan jenis ciri khas macam apa yang ingin dibuat oleh santri dan masyarakat sekitar. Hal seperti ini penting dilakukan. Seperti halnya yang diungkapkan oleh seorang warga: "Pemilihan ciri khas dan pembuatannya itu perlu dilakukan supaya dikenal oleh orang banyak. Karena ini bukan jangka pendek. Serta pendanaan, pembukuan yang apik pun harus dimiliki oleh setiap yang melakukan bisnis online (Wawancara dengan Ibu KM, warga sekitar, 29 September 2019).

Pelatihan bisnis online seperti ini merupakan sesuatu yang baru di kalangan santri, apalagi harus menyampaikan kepada masyarakat sekitar, terutama ibu-ibu. Selama ini mereka hanya di dapur saja. Tapi jika nantinya program ini berkembang sangat besar dan dilaksanakan dengan baik, masyarakat berharap dapat memutuskan barang seperti apa yang akan dibuat dengan ciri khasnya dan mengembangkannya 
dalam bisnis online. Begitu pula halnya dengan jasa. Sebab, kajian telah menunjukkan perlunya upaya bersama untuk mendukung bisnis online bagi masyarakat (Kusuma \& Rahman, 2018).

Hasil pengamatan yang dilakukan peneliti melalui analisis data bahwa pemberdayaan masyarakat tentunya menjadikan masyarakat menjadikan subyek yaitu pelaku. Masyarakat yang melakukan kegiatan tersebut secara mandiri untuk kepentingan pribadinya. Karena, dengan menempatkan masyarakat sebagai subyek pemberdayaan, masyarakat dapat belajar dan mengetahui masalah yang sedang dihadapinya.

Dilihat dari Teori Mobilisasi Sumber Daya, gerakan sosial terdiri dari individuindividu dan interaksi diantara anggota masyarakat. Pada konteks pemberdayaan masyarakat maka teori mobilisasi menjadi salah satu dasar yang kuat. Karena, untuk menjadi seorang atau kelompok masyarakat yang berdaya harus memiliki power selain biaya. Knowledge dan people juga mempunyai peranan penting. Kumpulan orang akan memberikan kekuatan, kekuatan itu akan menjadi power pada orang atau masyarakat. Jika dilihat dari apa yang telah dilakukan oleh Pesantren Persis No. 97 Cikajang ini merupakan suatu gerakan sosial oleh lembaga, dimana pihak lembaga tersebut mempunyai kekuatan santri dan juga knowledge.

Bila dilihat dari hasil wawancara dan fakta yang ada di lapangan bahwasanya masyarakat cukup berdampak apa yang telah pesantren lakukan dimulai dari program bidang sosial Baitul Mal, bidang Pendidikan agama adanya Taman Pendidikan Al Qur'an dan pengajian remaja, serta bidang ekonomi yakni Koperasi simpan pinjam, 
kelompok ternak, dan keterampilan masyarakat. Namun untuk bisnis online, mereka belum tergerak untuk mengikutinya.

Evaluasi sebagai upaya untuk melihat hasil dari proses pembelajaran dan pelatihan akan dilakukan sebelum dan sesudah pelatihan. Yaitu, pertanyaan yang sama baik untuk pre-test maupun post-test diberikan kepada peserta untuk dijadikan standardisasi pengujian. Evaluasi kegiatan juga dilakukan melalui testimoni-testimoni dari para peserta dan masyarakat sekitar tentang kesan mereka terhadap kegiatan ini.

\section{E. KESIMPULAN}

Berdasarkan hasil observasi dan kajian di lapangan, dapat disimpulkan bahwa hubungan kerjasama antara perguruan tinggi dan pesantren dapat mengembangkan bisnis online di masyarakat, yakni dapat dilihat sebagai berikut:

1. Cara meningkatkan pemahaman dan pengetahuan ustadz/ah dan santri pesantren terhadap bisnis online adalah dimulai dengan interaksi. Interaksi yang timbul dengan adanya pelatihan bisnis online dapat diketahui perbedaannya lewat ketepatan penyampaian informasi melalu target audience yang sesuai, perlengkapan sarana dan fasilitas komunikasi antar para pelaku kreatif, dan kondisi budget dalam memenuhi kebutuhan pelatihan maupun kreativitas santri/masyarakat.

2. Cara mengaplikasikan pengetahuan dan kemampuan bisnis online bagi ustadz/ah dan santri pesantren adalah dengan cara-cara praktis. Di sini diperlukan beberapa faktor pendukung adanya interaksi antar pelaku kreatif dengan masyarakat yaitu melalui rasa ketertarikan peserta atas kegiatan yang 
dilaksanakan santri, cara penyampaian informasi yang baik, jalinan hubungan cooperation (kerja sama) dan kelengkapan sarana pendukung.

3. Cara memproyeksikan peran pesantren bagi masyarakat desa dalam pengembangan bisnis online adalah dengan cara mempertahankan hubungan antar berbagai stakeholder bisnis online. Adapun upaya dilakukan santri untuk mempertahankan hubungan tersebut dengan tahapan mereka menjaring orangorang dan pihak-pihak potensial, tahap menjalin hubungan yang awet dan tahap memberikan imbalan kepada masyarakat berupa kontribusi langsung.

\section{DAFTAR PUSTAKA}

Abdullah, Aceng. (2004). Press Relations: Kiat Berbubungan dengan Media Massa. Bandung: Rosda Karya.

Alfurqon, Hanif Syaifudien. (2012). Minat Siswa Smk Melanjutkan Studi Ke perguruan Tinggi Pada Siswa Kelas XII Jurusan Teknik Kendaraan Ringan SMK Negeri 2 Surakarta Tabun Ajaran 2011/2012. Surakarta: Universitas Sebelas Maret.

Anwar, R. K., Lusiana, E., \& Rahman, M. T. (2019). Internet Advertising and Consumptive Lifestyle of the Students. TEMALI: Jurnal Pembangunan Sosial, 2(1), 46-60.

Arifin, Muzayyin. (2003). Kapita Selekta Pendidikan Islam. Jakarta: PT Bumi Aksara. Asy'ari, Sapari Imam. (1993). Sosiologi Kota Dan Desa, Surabaya: Usaha Nasional. Azwar, Saifuddin. (2000). Sikap Manusia: Teori dan pengukurannya. Yogyakarta: Pustaka Pelajar. 
Basundoro, Purnawan. (2001). Industialisasi, Perkembangan Kota, dan Respon Masyarakat Studi Kasus Kota Gresik, Jurnal Volume XIII, No.2/2001.

Bungin, Burhan. (2001). Metodologi Penelitian Sosial. Surabaya: Airlangga University Press.

Bungin, Burhan. (2006). Sosiologi Komunikasi. Jakarta: Prenada Media Group.

Clutterbuck, David dan Susan Kornaghan. (2010). The Power of Empowerment Release the Hidden Talents of your Employees. Jakarta: Bhuana Ilmu Populer.

Daldjoni. (1992). Seluk Beluk Masyarakat Kota. Bandung: Alumni.

Darmansyah. (1986). Ilmu Sosial Dasar. Surabaya: Usaha Nasional.

De Vito, Joseph A. (1997). Komunikasi Antar Manusia. Jakarta: Profesional Books.

Dhofier, Zamakhasary. (1984). Tradisi Pesantren-Studi Tentang Pandangan Hidup Kyai, Jakarta: LP3ES.

Djamaluddin, \& Abdullah Aly. (1998). Kapita Selekta Pendidikan Islam, Bandung: Pustaka Setia.

Effendy, Onong Uchjana. (2000). Ilmu Teori dan Filsafat Komunikasi. Bandung: Citra Aditya Bakti.

Fadjar, A. Malik. (2005). Holistik Pemikiran Pendidikan, Jakarta: Rajagrafindo Persada. Faristin, Hindun. (2008). "Pengelolaan Bisnis Islam Sektor Agribisnis dalam Usaha Pemberdayaan Masyarakat Muslim", STAIN Kudus, Skripsi, 2008.

Gunawan, Ary H. (2000). Sosiologi Pendidikan, Jakarta: Rineka Cipta.

Gunawan, Imam. (2013). Metode Penelitian Kualitatif: Teori dan Praktik. Jakarta: PT. Bumi Aksara. 
Haedari, Amin. (2004). Masa Depan Pesantren: Dalam Tantangan modernitas dan Tantangan Kompleksitas Global. Jakarta: IRD Press.

Halim, Suhartini A. dkk. (2005). Model-Model Pemberdayaan Masyarakat. Yogyakarta: Pustaka Pesantren.

Hasbullah. (1996). Sejarah Pendidikan Islam di Indonesia, Jakarta: PT. Raja Grafindo. http://e-journal.uajy.ac.id/11311/4/3MTA02155.pdf, diakses tanggal 1 November 2018.

http://repository.unisba.ac.id/bitstream/handle/123456789/5297/06Bab2 Dewand a. 10070311059 skr 2015.pdf?sequence $=6$ \&isAllowed $=y$, diakses tanggal 26 Oktober 2018.

https://media.neliti.com/media/publications/77601-ID-pengembangan-industrikreatif-di-kota-ba.pdf, diakses tanggal 05 Oktober 2018. https://regional.kompas.com/read/2015/12/12/12351701/UNESCO.Masukkan.K ota.Bandung.dalam.Jaringan.Kota.Kreatif, diakses tanggal 21 Oktober 2018 Ikbar, Yanuar. (2012). Metode Penelitian Sosial. Bandung: Refika Aditama. Jamaludin, Adon Nasrullah. (2015). Sosiologi Perkotaan, Bandung: Pustaka Setia. Johnson, Doyle Paul. (1986). Teori Sosiologi Klasik dan Modern jilid II. Jakarta: PT. Gramedia Pustaka.

Juju dan Feri Sulianta. (2010). Kiat Sukses Menjadi IT Freelance. Jakarta: Elex Media Komputido.

Kusuma, M., \& Rahman, M. T. (2018). The role of social institutions on online business development in Cimahi, West Java, Indonesia. Jurnal Socio-Politica, 8(2), 165-173. 
Maarif, Syamsul. (2010). Bahan Ajar Sosisologi. Perilaku Kolektif \& Gerakan Sosial. Yogyakarta: Gress Publishing.

Makmun, Abin Syamsuddin. (2002). Psikologi Kependidikan. Perangkat Sistem Pengajaran Modul. Bandung: Rosdakarya.

Mar'at. (1981). Sikap Manusia, Perubahan serta Pengukuran. Jakarta: Ghalia Indonesia.

Maulana, Hilman. (2017). Pengembangan Industri Kreatif dalam Meningkatkan Kesejabteraan Masyarakat. Bogor.

MeNair, Brian. (2015). Pengantar Komunikasi Politik. Bandung: Nusa Media.

Michael Sipahelut. (2010). Analisis Pemberdayaan Masyarakat Nelayan di Halmahera Utara. Tesis, IPB Bogor.

Moelyono, Mauled. (2010). Menggerakkan Ekonomi Kreatif. Jakarta: Rajagrafindo Persada.

Muiz, Yusuf . (2017). Persepsi Masyarakat Pada Pembangunan Gedung Bandung Kreatif Hub. Bandung.

Nata, Abudin. (2001). Sejarah Pertumbuban Lembaga-Lembaga Pendidikan Islam di Indonesia, Jakarta: Gramedia.

Nurlia. Lia. (2018).Pola Interaksi dan Solidaritas Sosial Komunitas Penggemar Korean Pop (KPOP). Bandung.

Otnes, C. (2017). Mind, Self and Consumption: George Herbert Mead. In Canonical Authors in Consumption Theory (pp. 113-119). Routledge.

Outhwaite, William. (2008). Kamus Lengkap Pemikiran Sosial Modern. Jakarta: Prenada Media Group. 
Rahim, Husni. (2001). Arah Baru Pendidikan Islam di Indonesia, Jakarta: Logos.

Rahman, M. Taufiq. (2011). Glosari Teori Sosial. Bandung: Ibnu Sina Press.

Rahman, M. Taufiq. (2018). Pengantar Filsafat Sosial. Bandung: LEKKAS.

Ramelan, Rahardi. (2008). Teknologi dan Masyarakat. Bandung: CV. Lubuk Agung.

Ritzer, George. (2014). Teori Sosiologi Modern. Jakarta: Prenadamedia Group.

Sajogyo, Pudjiwati. (2011). Sosiologi Pedesaan, Yogyakarta: Gajah Mada University Press.

Setiadi, Elly M. dan Usman Kolip. (2011). Pengantar Sosiologi Pemabaman Fakta dan Gejala Permasalahan Sosial: Teori, Aplikasi dan Pemecahannya. Jakarta: Prenada Media Group.

Setiawan, Iwan. (2012). Agribisnis Kreatif Pilar Wirausaba Masa Depan, Kekuatan Dunia Baru Menuju Kemakmuran Hijau. Depok: Penebar Swadaya.

Sobur, Alex. (2013). Semiotika Komunikasi. Bandung: Alfabeta.

Soekanto, Soerjono. (2013). Sosiologi Suatu Pengantar. Jakarta: Rajagrafindo Persada.

Sopandi, Andi. (2009). Strategi Pemberdayaan Masyarakat, Jurnal Madani, Volume 1, nomor 2, Nopember.

Sudiyono. (2004). Manajemen Pendidikan Tinggi, Jakarta: Rineka Cipta.

Suharto, Edi. (2005). Membangun masyarakat memberdayakan rakyat. Bandung: Refika Aditama.

Suparman, Oman. (2016). Kiat Menjadi Pengusaha Muda yang Tangguh dan Inovatif. Bandung: Boenz Enterprise.

Suryana. (2013). Ekonomi Kreatif, Ekonomi Baru: Mengubah Ide dan Menciptakan Peluang. Jakarta: Salemba Empat. 
Syah, Muhibbin. (2002). Psikologi Pendidikan : Dengan Pendekatan Baru. Bandung: Rosdakarya.

Syahputra, Iswandi. (2007). Komunikasi Profentik Konsep dan Pendekatan. Bandung: Simbiosa Rekatama Media.

Tan, Alexis S. (1981). Mass Communication Theories and Research. Ohio: Grid Publishing Inc.

Wahjoetomo. (1997). Perguruan Tinggi Pesantren, Cet. I, Jakarta: Gema Insani Pers.

Widjajanti, Kesi. (2011). Model Pemberdayaan Masyarakat, Jurnal Ekonomi Pembangunan, Volume 12, nomor 1, Juni.

Yacub. (1984). Pondok Pesantren dan pembangunan Masyarakat Desa. Bandung: Angkasa.

Yusup, Pawit M. (1990). Komunikasi Pendidikan dan Komunikasi Instruksional. Bandung: Remaja Rosdakarya.

Ziemek, Manfred. (1986). Pesantren Dalam Perubahan Sosial, Jakarta:, P3M, cet. I.

Zuhairini. (1992). Filsafat Pendidikan Islam, Jakarta: Bumi Aksara. 